\title{
Тувинское буддийское паломничество: от традиции к вере
}

Чимиза К. Ламажаа

Калмыцкий государственный университет им. Б. Б. Городовикова, Российская Федерация,

\author{
Ульяна П. Бичелдей, Айлаана В. Монгуш
}

Тувинский институт гуманитарных и прикладных социально-экономических исследований при Правительстве Республики Тыва, Российская Федерация
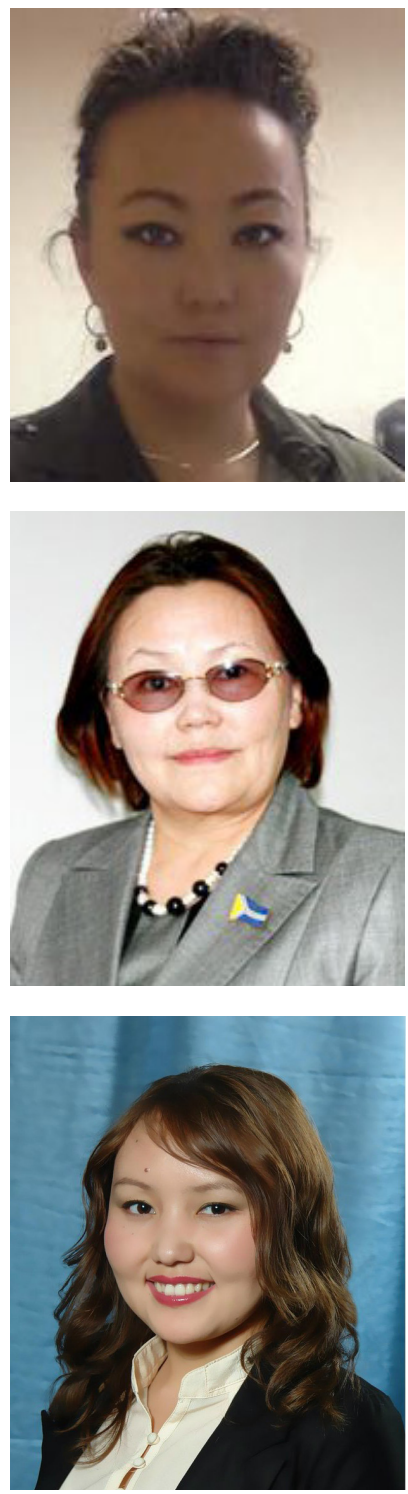

В статье анализируется современное буддийское паломничество тувинцев как социиальная практика, социальное движение. Источниковой базой выступили материалы полуформализованных интервью с 11 тувинцами, сопровождающими религиозных паломников и участниками заграничных паломнических туров, записанные в феврале-марте 2020 г. в г. Кызыле.

Первая паломническая поездка тувинцев в постсоветское время в Индию, где ныне находится центр тибетского буддизма с его лидером, состоялась в 1995 г. В 1997 г. на учебу выехали первые ученики. Паломнические туры впоследствии стали организовываться с начала 2000-х гг. Организаторы - ламы Тувы, первые паломники, которые получили опыт. Социальное движение развивается как стихийный процесс. Выезжают паломники за границу разрозненно, в основном группами, централизованной организации нет.

Направления паломнических поездок - зарубежные (резиденция Его Святейшества Далай-ламы XIV в индийской Дхарамсале, святые места, связанные с жизнью Будды Шакьямуни; Непал, Тибет, Монголия; западные страны, где дает Учения Далай-лама), российские (Бурятия, Калмыкия, Санкт-Петербург, где расположены буддийские храмы, центры); по Туве.

Опыт паломничества мирян в форме религиозного туризма позволяет в дальнейшем им развить в себе интерес к буддизму настолько, что способствует именно внутреннему переходу от «буддиста по традиции» $-\kappa$ «буддисту по вере».

Ключевые слова: Тува; буддизм; тувинский буддизм; тувинцы; религиозность; паломничество; религиозный туризм; Далай-лама; Индия; Непал; Тибет; Монголия; Латвия

Статья подготовлена при финансовой поддержке Российского научного фонда в рамках научного проекта «Россия и буддийский мир в дискурсе философского востоковедения» (грант № 19-18-00118).

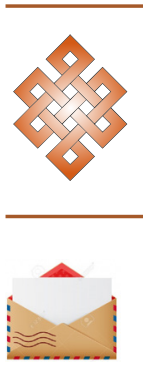

Для цитирования:

Ламажаа Ч. К., Бичелдей У. П., Монгуш А. В. Тувинское буддийское паломничество: от традиции к вере // Новые исследования Тувы. 2020, № 4. С. 135-155. DOI: www.doi. org/10.25178/nit.2020.4.10

Бичелдей Ульяна Павловна - доктор религиоведения (PhD), руководитель научноисследовательской группы религиоведения Тувинского института гуманитарных и прикладных социальноэкономических исследований при Правительстве Республики Тыва. Адрес: 66700, Россия, г. Кызыл, ул. Кочетова, д. 4. Тел.: +7 (394-22) 2-39-36. Эл. адрес: opei-ool@yandex.ru

Монгуш Айлаана Витальевна - научный сотрудник научно-исследовательской группы религиоведения Тувинского института гуманитарных и прикладных социально-экономических исследований при Правительстве Республики Тыва. Адрес: 667000, Россия, г. Кызыл, ул. Кочетова, д. 4 . Тел.: +7 (394-22) 2-39-36. Эл. адрес: ailaashka_88@mail.ru 


\title{
Tuvan Buddhist pilgrimage: from tradition to the faith
}

\author{
Chimiza K. Lamazhaa \\ B. B. Gorodovikov Kalmyk State University, Russian Federation, \\ Ulyana P. Bicheldey, Aylaana V. Mongush
}

Tuvan Institute of Humanities and Applied Social and Economic Research under the Government of Tuva, Russian Federation

The article examines the contemporary Buddhist pilgrimage in Tuva as a social practice and movement. For its sources, it relies on semi-formal interviews, recorded in February and March 2020 in Kyzyl, with 11 Tuvans who accompanied religious pilgrims, or themselves participated in foreign pilgrimage tours.

The first pilgrimage Tuvans undertook in post-Soviet period occurred in 1995, and its destination was India, which is now the center of Tibetan Buddhism and the country of residence of its leader. The first students of Buddhism went there in 1997. Pilgrimage tours were subsequently organized in the early 2000s by Tuvan lamas and first pilgrims who had returned from India earlier. This social movement was developing spontaneously, with pilgrims going abroad separately or in groups, as a centralized structure did not exist at the time.

There are three types of destinations popular among pilgrims: foreign locations (residence of His Holiness the Dalai Lama XIV in Dharamsala, India, holy places associated with the life of Shakyamuni Buddha; Nepal, Tibet, Mongolia; Western countries where the Dalai Lama lectures on his teachings), Russian locations (Buryatia, Kalmykia and Saint Petersburg, where Buddhist temples and centers are located), and locations in Tuva proper.

The experience of lay pilgrimage in the form of religious tourism allows them to develop an interest in Buddhism to a degree which helps start the internal transition from a "traditional Buddhist" to a "devout Buddhist".

Keywords: Tuva; Buddhism; Tuvan Buddhism; Tuvans; religiousness; pilgrimage; religious tourism; Dalai Lama; India; Nepal; Tibet; Mongolia; Latvia

\section{Financing}

The article was prepared with support from the Russian Science Foundation, Grant No. 19-18-00118,

«Russia and the Buddhist world in the discourse of the philosophy of Oriental Studies».

\section{For citation:}

Lamazhaa Ch. K., Bicheldey U. P. and Mongush A. V. Tuvinskoe buddiiskoe palomnichestvo: ot traditsii k vere [Tuvan Buddhist pilgrimage: from tradition to the faith]. New Research of Tuva, 2020, no. 4, pp. 135-155. (In Russ.). DOI: www.doi. org/10.25178/nit.2020.4.10

LAMAZHAA, Chimiza Kuder-oolovna, Doctor of Philosophy, Visiting Researcher, Kalmyk State University. Postal address: Office 111, 11 Pushkin St., 358000 Elista, Russian Federation. Tel.: +7 (916) 413-3385.E-mail: lamazhaa@tuva.asia ORCID ID: 0000-0003-1813-3605

BICHELDEY, Ulyana Pavlovna, Doctor of Religious studies (Ph.D), Head, Religious studies unit, Tuvan Institute for the Humanities and Applied Social and Economic Studies. Postal address: 4 Kochetov St., 667000 Kyzyl, Russian Federation. Tel.: +7 (394-22) 2-39-36. E-mail: opei-ool@yandex.ru ORCID ID: 0000-0001-5588-9167

MONGUSH, Aylaana Vitalyevna, Researcher, Religious studies unit, Tuvan Institute for the Humanities and Applied Social and Economic Studies. Postal address: 4 Kochetov St., 667000 Kyzyl, Russian Federation. Tel.: +7 (39422) 2-39-36. E-mail: ailaashka_88@mail.ru ORCID ID: 0000-0002-3164-1463 


\section{Введение}

Буддийское паломничество тувинцев на сегодня является практически не изученным наукой, несмотря на значительное число трудов в целом по истории буддизма в Туве и его современному состоянию в республике (Монгуш, 1992, 2001; Жуковская, 1992; Хомушку, 1998, 2005; Абаев, Хомушку, Бичелдей, 2013; Хомушку, Кухта, 2016; Ламажаa, 2019 и мн. др.). При этом, надо подчеркнуть, что это движение не исследовано ни в исторических формах, ни в современных. В ряде работ историков буддизма можно встретить лишь отдельные сведения о паломничестве тувинцев на рубеже XIX-XX веков в пределах своей республики, в Монголию (Монгуш, 2001: 45, 47, 48; Буддизм, 1992: 16711). Сведения о поездках лам в монастыри Тибета для получения образования можно найти в фондах Национального архива Республики Тыва (НА РТ), Научного архива Тувинского института гуманитарных и прикладных социально-экономических исследований при Правительстве Республики Тыва (НА ТИГПИ) ${ }^{2}$. Но они пока не опубликованы, не введены в научный оборот. Некоторые упоминания о тувинцах-паломниках встречаются в исследованиях буддийского паломничества народов Центральной Азии (Гучинова, 2020ab; Дариева, Гучинова, 2020; Павличенко, Давыденко, 2018; Мунхбат, 2018; Ерохина, 2019; Эрендженова, 2020 и др.).

Сегодня, учитывая общий научный интерес к теме современного религиозного паломничества, необходимость изучения тувинского его варианта в XXI веке, динамики, состава участников, их мотивации, маршрутов и пр. - уже со всей очевидностью назрела. Кроме этого, это важно для понимания особенностей функционирования буддийского Учения сегодня среди его последователей в Туве, представлений о религиозности населения республики.

Источниковой базой нашего исследования стали материалы полуформализованных интервью с 11 тувинцами, мужчинами и женщинами - сопровождающими религиозных паломников и участниками заграничных паломнических туров, которые мы записали в феврале-марте 2020 г. в г. Кызылез Каждое интервью длилось около часа или более часа, записи сделаны на цифровые носители, затем расшифрованы; стенограммы хранятся в архивах соавторов (далее - полевые материалы авторов, ПМА, 2020). В том числе мы учитывали имеющиеся публикации о современном состоянии буддизма в Туве (в научных источниках, а также СМИ, социальных сетях).

Важным для интервьюирования и обсуждения вопросов мотивов духовных поисков мы считали получение доверия от наших респондентов. Его достигали благодаря тому, что, во-первых, главный интервьюер - У. П. Бичелдей - является сама буддистом, долгое время возглавляла тувинское общество «Друзья Тибета» и поэтому воспринималась собеседниками как инсайдер, и это располагало к откровенности; во-вторых, общение велось с респондентами как на русском, так и на тувинском языке, что позволяло нашим собеседникам не испытывать языковых затруднений в выражении сокровенных мыслей.

\section{Исследования паломничества в современном мире}

За много веков своей истории религиозное паломничество выступало как одна из старейших и основных форм мобильности населения (Collins-Kreiner, 2010). Конечно, как феномен социокультурной жизни оно меняло свои формы, маршруты (Ваторпин, Костина, Подергина, 2017), но в целом, было и остается обязательной частью религиозного культа. Оно предполагает в своей сути восстановление контакта мирского со священным (Уланов, Бадмаев, Андреева, 2020: 398; Калужникова, 2007). Однако, в условиях глобализированного мира и развития различных форм туризма, паломничество в XXI веке стало представляться и как номадические перемещения в рамках своих религиозных культурных ландшафтов (Кормина, 2019), и как особое направление межкультурных коммуникаций (Житнев, 2010). Оно приобрело тесную связь с туризмом, в рамках которого имеет особый вид - религиозный туризм, а в иных случаях рассматривается само как разновидность религиозного туризма.

\footnotetext{
${ }^{1}$ См. также из воспоминаний: Дамдын А. Төөгулуг одуруглар [Исторические строки] // Самагалдай - тываның баштайгы найысылал [Самагалдай - первая столица Тувы]. Кызыл: Новости Тувы, 1996. С. 99-100. (На тув. яз.). ${ }^{2}$ Одна из интересных в этом плане рукописей - О. Ч. Люндупа «Воспоминания о ламской церкви в Туве» (1970-1973 гг.) - из рукописного фонда НА ТИГПИ в настоящее время готовится к публикации одним из соавторов данной статьи.

${ }^{3}$ Мы также даем в статье некоторые мнения, воспоминания из интервью отдельными цитатами (с незначительным редактированием стиля устной речи и с переводами с тувинского языка на русский). Пять из 11 человек просили не называть их имена, в этих случаях мы ставим только инициалы. По некоторым очень личным высказываниям мы анонимизировали слова всех респондентов.
} 
Выделение паломничества в особую область исследований началось с работы 1978 г. Э. и В. Тёрнер «Image and Pilgrimage in Christian Culture» («Образ и паломничество в христианской культуре») (TurnerV., Turner Е., 1978). На сегодня, как пишут Б. Ким, С. Ким и Б. Кинг, в многочисленных исследованиях паломничества и религиозного туризма можно насчитать в общей сложности 84 тематизма. Они возникают благодаря множественности подходов, как дисциплинарных, так и междисциплинарных, распространяющихся на различные методы, темы, приложения, географические очаги и проявления этого явления (Kim B., Kim S., King, 2020). Интересные результаты и заключения даны в авторских монографических изданиях (Sellner, 2004; McIntosh, 2020 и др.), статьях (Coleman, 2002) и коллективных сборниках (Reframing pilgrimage ..., 2009; Shrines and pilgrimage ..., 2008; Паломничество и религиозный ..., 2011; Феномен паломничества ..., 2006; Raj, Gfiffin, 2015).

Паломничество исследователями определяется в целом как поклонение святым местам, которые могут быть как в иных странах (внешнее, зарубежное паломничество), так и внутри своей, но вне пределов своего постоянного места жительства (внутреннее) (Житенев, 2012: 19). У приверженцев тибетского варианта буддизма для обозначения паломничества имеется тибетский термин накхор (gnas- 'khor обход по кругу), который совершается «с целью очиститься от мирской скверны, накопить “заслуги” на пути к просветлению, получить благословение святого подвижника или приобщиться к святости свящ. предмета или святого места» (Буддизм, 1992: 188). В первую очередь объектами поклонения этих буддистов являются места, связанные с Буддой - в Индии, Непале. Помимо них святыми считаются и места жизнедеятельности других буддийских учителей: в Тибете (с 1950 г. в составе Китайской Народной Республики), в Монголии. Если брать расширенное толкование термина, то посещение и обход мест, где когда-то бывали святые личности и тем самым освятили это пространство, в ознаменование чего возводятся храмы, ступы либо другие культовые сооружения (Эрендженова, 2020: 127), то очевидно, что буддийское паломничество может рассматриваться как внутреннее (в пределах своего региона или страны) и как внешнее (на территорию другой страны). Более того, исследователи даже трактуют в качестве особого вида буддийского паломничества участие бурятской делегации на коронации российского императора Николая II в 1896 г. (Цыремпилов, 2020).

Интерес российской науки к проблематике современного паломничества, причем конкретно буддийского, в этом году, например, выразился в специальных выпусках одновременно сразу в двух ведущих журналах в антропологии и религиоведении - соответственно: «Этнографическом обозрении» (№ 22020 года) с темой «Практики буддийского паломничества в России» ${ }^{1}$ и «Государство, религия, церковь» (№ 12020 года) с темой «Тибето-монгольский буддизм: новые траектории в XX-XXI вв.»². В них можно увидеть разные работы, но, к сожалению, среди них нет ни одного тувинского кейса.

Мы постараемся восполнить этот пробел, одновременно продолжая наши исследования современного состояния буддийской культуры в Туве (Ламажаа, 2019; Бадмаев и др., 2020). Нас интересуют прежде всего те виды паломничества, которые связаны с выездом за пределы Тувы и России и на сегодня тесно переплелись с видами зарубежного туризма.

Паломничество мы рассматриваем как своего рода социальное движение, имея в виду его внеинституциональный характер, отмеченный Э. Гидденсом (Гидденс, 1999: 585). При этом, в отличие от гидденсовского социального движения, имеющего общие цели, тем не менее результаты и процесс целедостижения паломничества - это индивидуальная или групповая практика. Однако, как указывают А. С. Ваторпин, Н. Б. Костина и Е. Е. Подергина, социальные параметры всегда присутствовали в паломничестве, а в современном мире оно трансформировалось в целом в социальную практику, в том числе став регулируемым нормами права (Ваторпин, Костина, Подергина, 2017: 54).

\section{Организация паломнических поездок}

Постсоветское возрождение буддизма в России началось с того, что в 1988 г. в ряде советских территорий были зарегистрированы немногочисленные буддийские общины, подчинявшиеся Центральному духовному управлению буддистов (ЦДУБ). Одновременно стали возникать буддийские общины в Калмыкии (История буддизма ..., 2010: 70), Туве, Москве, Ленинграде (Санкт-Петербурге), а затем и других городах России и бывшего СССР (Жуковская, 2013: 51). В Туве 25 января 1990 г. было официально зарегистрировано Тувинское общество буддистов (История буддизма ..., 2010: 117). В этом же году

\footnotetext{
${ }^{1}$ https://ras.jes.su/ethnorev/issue.2020.2.4.2-ru-2-3-4-5

${ }^{2}$ https://religion.ranepa.ru/sites/default/files/GRC\%201\%202020\%20Final+.pdf
} 
впервые после долгого перерыва был избран глава буддистов республики - Камбы-лама (там же: 121). Связи буддистов с внешним миром стали расширяться. Ученики из Тувы в 1991 г. поступили в Буддийский институт Даши Чойгхорлинг в Бурятии (в числе 96 человек - сразу из нескольких регионов России и Монголии) (там же: 105).

Но самым мощным фактором для развития процесса стали официальные визиты Его Святейшества Далай-ламы XIV во главе правительственной делегации Тибета в российские регионы.

В Туву такой первый визит буддистского духовного лидера состоялся в 1992 г. и стал большим событием в культурной жизни республики. Тогда между Тувой и с Администрацией Правительства Его Святейшества Далай-ламы XIV было подписано двустороннее соглашение о сотрудничестве в области культуры и религиозного образования.

Гости по просьбе тувинской стороны приняли на себя обязательство направить в Туву двух тибетских учителей-лам для оказания помощи в распространении учения Будды среди тувинских верующих (что и было впоследствии сделано). Со своей стороны тувинская сторона выразила желание направить на учебу в тибетские монастыри Индии группу хуураков. Однако прежде всего в 1995 г. в Индию отправилась официальная делегация Республики Тыва (из 9 человек) на торжества, посвященные 60-летию Его Святейшества Далайламы XIV, которые прошли в г. НьюДели и Дхарамсале 3-9 июля. Делегацию возглавил председатель Верховного хурала Республики Тыва К. А. Бичелдей. В составе была также одна из соавторов данной статьи У. П. Бичелдей (Опей-оол) (фото 1). Также при поддержке руководства республики была сформирована отдельно и группа паломников из Тувы (состояла из 10 человек), которая отправилась туда самостоятельно и тем

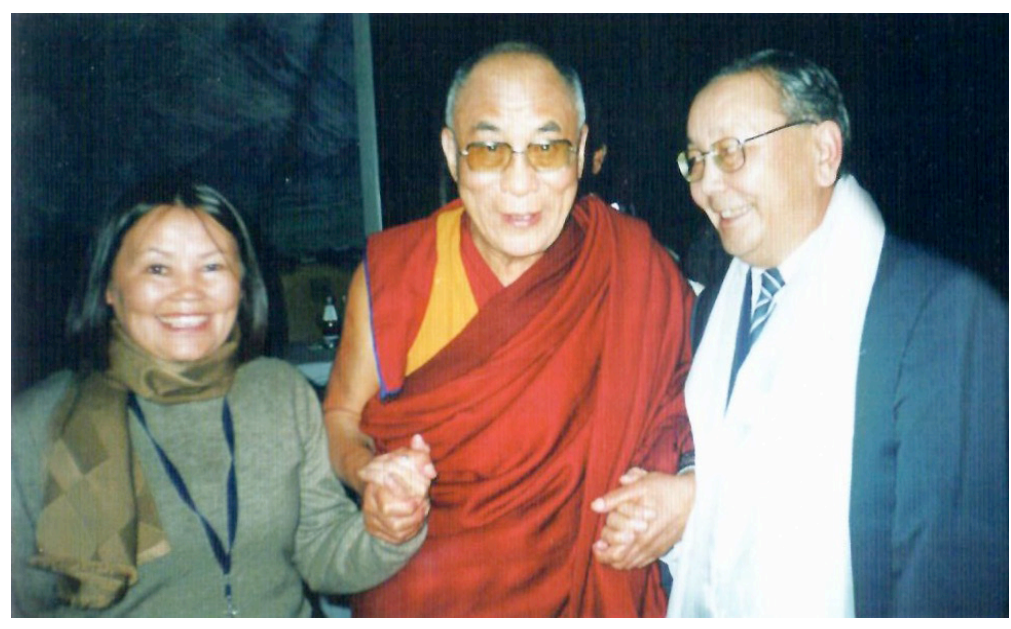

Фото 1. Ульяна Бичелдей (Опей-оол), Каадыр-оол Бичелдей с Его Святейшеством Далай-ламой XIV, 2009 г. Фото из архива семьи Бичелдей.

Photo 1. Ulyana Bicheldey (Opei-ool) and Kadyr-ool Bicheldey with His Holiness Dalai Lama XIV, 2009. Photo from the Bicheldey family archive. самым фактически стала первой группой паломников тувинцев-буддистов в Индию постсоветского времени.

Обе группы - официальная и паломников - встретились уже в Нью-Дели. На приеме у Его Святейшества Далай-ламы XIV K. А. Бичелдей представил главе буддистов мира и членов делегации, и паломников.

Первые шесть тувинских юношей на обучение в Индию отправились в 1997 г. Они были приняты в буддийский университет Гоман монастыря Дрепунг (штат Карнатака). Одним из них был Буян башкы (учитель Буян, как его называют буддисты Тувы, или в миру - Буян Сандык). Его духовное имя гелонг Тензин Чинба, в 2011 г. он стал председателем администрации Объединения буддистов Тувы, сегодня работает в Управлении Камбы-ламы Республики Тыва. Буян башкы также выступил нашим респондентом и поделился своими воспоминаниями о первой и последующих поездках ${ }^{1}$ :

«В 1997 г. нас было 6 человек... Впервые мы тувинцы туда поехали учиться. Я тогда только “разведывал”, что такое Индия, монастыри, Его святейшество Далай-Лама, монахи...

В первый раз, когда я отправился в Индию учиться, было очень тяжело. Мне было 30 лет,

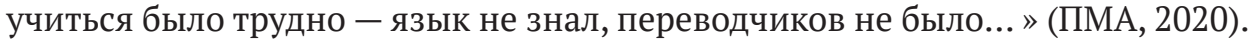

Там он получил первое свое благословение, но заболел из-за непривычного тропического климата.

1 Дополнительная информация восстановлена из его интервью тувинской газете «Центр Азии»: Тензин Чимба (Буян Сандык): «Все мы одинаковы. Все страдаем. Все хотим счастья» (беседовала Инна Черкасова-Тонгак) [Электронный ресурс] // Центр Азии (газета). 2004, № 7. URL: http://www.centerasia.ru/issue/2004/7/1481-tenzinchimbabujan-sandyk-vse-my.html (дата обращения: 12.08.2020). 
Вернулся домой лечиться, а пятеро его земляков остались. Свое решение посвятить жизнь религии он не оставил, поэтому в 2001 г. снова вернулся на учебу в Индию:

«Тогда я на себе почувствовал, что значит монастырский быт, расписание, учеба. Учиться надо было 15 лет - 15 курсов, на каждом курсе примерно по сто учащихся. Моими одноклассниками были десятилетние мальчишки - ровесники детей моих друзей, ... получалось, что я учусь в одном классе как бы с детьми друзей» ${ }^{1}$

Он снова не удержался на месте, а когда в третий раз вернулся в эту страну, то там ему пришла в голову идея:

«... если я не могу учиться, то в моих силах отправлять учиться в Индию тувинских мальчишек, которые хотят стать монахами, конечно, отправлять с согласия родителей. И в моих силах им помочь. Начинал с того, что объяснял, как живут монахи. При храме (имеется в виду Цеченлинг, центральный буддийский храм Тувы. - Ч. Л., У. Б., А. М.) устраивали что-то вроде подготовительных курсов. И уже затем искали спонсоров, проводили марафоны, концерты, чтобы отправить ребят в Индию, потому что не все семьи могли собрать средства на дорогу. Провожал их до Москвы, сажал в самолет, получал подтверждение из Индии о том, что все в порядке: группа долетела, их встретили. Только после этого возвращался в Туву»².

Так, с 2003 г. он стал отправлять мальчиков на обучение. Но, помимо этого, стал и сопровождать взрослых паломников: давал объявления, собирал людей, помогал им делать визы и покупать билеты, сопровождал в Индию. Другие монахи, а затем уже и побывавшие в паломничествах миряне стали следовать его примеру. Тот факт, что в составе приезжих в Индию произошли значительные изменения именно за первые пять лет XXI века, подкрепляются наблюдениями тувинского историка буддизма М. В. Монгуш. В 1999 г. она в индийской Дхарамсале встречала россиян считанные единицы, а в 2005 г., когда снова вернулась туда, то уже часто слышала на улицах русскую речь (Монгуш, 2010: 326-327).

Буян башкы в первые годы ездил с группой из 30 человек. Затем в 2010-е гг. ее средняя численность возросла до 100 чел. Часть паломников, уже ознакомившись с маршрутом, получив опыт и определенные знания, параллельно начала ездить самостоятельно, в том числе порой и сами в свою очередь выступая в качестве организаторов паломнических поездок. Помимо этого, Буян башкы и просто помогал с организацией поездок групп без сопровождения.

Так, наша респондент А. впервые побывала в Индии в 2006 г. в составе группы, организованной под опекой Буяна башкы, но сопровождал людей другой паломник. Затем стала сама ездить туда, собирая свои группы. В общей сложности, по ее словам, она была в этой стране уже 11-12 раз (ПМА, 2020). Другая респондент Ч. М.-Х. Тензин, нынешний председатель тувинского общества «Друзья Тибета», впервые побывала в Индии в 2010 г. в составе группы подобных уже опытных тувинок, затем также стала регулярно ездить, в том числе беря с собой своих детей, других родственников, друзей. С ней стали связываться и другие желающие (ПМА, 2020).

Отдельные паломники отправляются спонтанно в одиночку, в поисках ответов на вопросы, которые возникли в их жизни:

«... Был случай, когда я не хотела жить... У меня переломный момент был в жизни, я потеряла своих детей... В это время Буян башкы говорил, что Его Святейшество Далай-Лама приезжает в Ригу. Я просто собрала чемодан и уехала одна. Ничего не знала, приехала в Ригу и там встретилась с буряткой...» (респондент Х., жен., 32 года; ПМА, 2020).

Аян-оол башкы (Лопсан Дондуп, в миру - Аян Херел-оол) окончил Тибетский медико-астрологический колледж «Мен-ци-канг» Дхарамсалы, получив целевое место при содействии Его Святейшества Далай-ламы XIV по просьбе руководства республики в 2007 г. Стал врачом тибетской медицины, практикует. Один из первых получивших в Туве в 2015 г. разрешение Министерства здравоохранения Республики Тыва на занятие народной медициной ${ }^{3}$. Также регулярно, дважды в год, выезжает в Индию и Тибет. Вместе с ним каждый раз, по его словам, отправляется по 50 человек. Причем, с ним едут, в основном, по его словам, каждый раз новые люди, в том числе много молодежи (ПМА, 2020).

\footnotetext{
${ }^{1}$ Тензин Чимба (Буян Сандык): «Все мы одинаковы. Все страдаем. Все хотим счастья» ...

2 Там же.

${ }^{3}$ В Туве впервые выданы официальные разрешения на занятие народной медициной [Электронный ресурс] //

Сохраним Тибет. 2015, 16 августа. URL: http://savetibet.ru/2015/08/16/tuva.html (дата обращения: 12.08.2020).
} 
Организаторы поездок за свою помощь, консультации, сопровождение денег не берут. Но выезжающие могут им оплачивать билеты, проживание, питание, хотя далеко не всегда. Порой на свои путевые расходы самим организаторам приходиться и копить свои средства в течение определенного времени, и просить помощи, как они выражаются, у «спонсоров» - друзей, родственников. В среднем поездка в 2019 г. в Индию обходилась в 100 тысяч рублей на одного человека, что для жителей Тувы весьма существенная сумма (если учитывать то, что по среднедушевому доходу населения в месяц Тува считается одним из самых бедных регионов России; в 2018 г. - 15603 руб.) ${ }^{1}$. Поэтому для такой поездки обычной практикой стало накопление средств в течение года, экономия обычных расходов, урезание бюджета. Хотя тувинцы с относительно высоким уровнем достатка могут и не прибегать к этому варианту, им достаточно получить отпускные или воспользоваться кредитной картой, о чем также говорили нам респонденты.

Выезжают паломники за границу разрозненно, Управление Камбы-ламы Республики Тыва в этом деле практически не участвует (оно до сих пор не имеет актуального сайта в Интернете, только ведутся страницы в социальных сетях), и даже если служащие в нем ламы занимаются организацией поездок, то это является практически их личным делом. Информация в первые годы передавалась из уст в уста, впоследствии распространились мессенджеры (наиболее популярный в Туве ныне Viber, а из социальных сетей - «ВКонтакте»), в них появились общие чаты, группы, страницы. Также паломники ориентируются на информацию, которая размещается на сайтах: фонда «Сохраним Тибет» (http://savetibet.ru/), русскоязычного сайта Его Святейшества Далай-ламы XIV (https://ru.dalailama. com/), Централизованной буддийской организации Дже Цонкапа (http:/geshe.ru/) и др. Люди иногда едут в одиночку, семейными группами, но чаще всего объединяются в малые или большие группы, стараются брать с собой детей, даже маленьких. Оформляют сообща визы, покупают вместе или по раздельности билеты, отправляются при помощи своих организаторов-сопровождающих из Тувы, а также присоединяются к группам паломников из Элисты, Москвы. Коллективные выезды удобнее, безопаснее, т. к. впервые выезжающие боятся потеряться, не владеют иностранными языками, не знают маршрутов, условий, цен и им важно иметь с собой опытного человека.

Соответственно, общей статистики тувинского паломничества нет, как и нет суммарных количественных данных по буддийским паломничествам калмыков и бурят. Нам говорили респондентыорганизаторы, что на учения Далай-ламы выезжают ежегодно от 100 до 300 тувинцев в отдельные годы. Но в целом, очевидно, можно насчитать 300-500 человек в год, отправляющихся в Индию, Китай (Тибет), Непал. И некоторое количество паломников - 100-200 человек - направляется за Далайламой в Латвию (об этом - далее) или в другую западную страну, где порой Далай-лама дает учения, например, в Испанию. Но это лишь приблизительные оценки, паломников может быть и больше. По гендерному составу, по словам организатора 3., обычно большинство составляют женщины: если едет группа в 30 чел., то только 5 чел. из них будут мужчины (респондент 3., жен., 53 г.; ПМА, 2020). По национальному составу - тут наши респонденты имели одно мнение: из Тувы практически всегда едут только тувинцы, русских жителей республики - не бывает.

\section{Марируты паломничеств}

Э.-Б. М. Гучинова в исследовании паломничества буддистов-калмыков отмечает, что в классической его форме самым престижным было путешествие в тибетскую столицу Лхасу - к его главному храму Зуу - к Большому Будде (Гучинова, 2020b: 38-39). В истории тувинского паломничества Тибет также был главным местом, однако, прежде всего для лиц, стремившихся получить ламское звание; миряне ездили на паломничества в Монголию. Сюда они ездили на рубеже XIX-XX в. помолиться в монастырях (Буддизм, 1992: 167), а также поклониться Восьмому Богдо-гэгэну Джебцуну Дамба хутухте 2 - тувинцы наравне с самими монголами почитали его божеством (Монгуш, 2001: 50).

Сегодня главным местом притяжения буддистов всего мира стало местопребывание Его Святейшества Далай-ламы XIV в индийской Дхарамсале и цель паломнических поездок связана в первую

\footnotetext{
1 Регионы России. Социально-экономические показатели. 2019. Стат. сб. М., 2019. https://rosstat.gov.ru/storage/ mediabank/Region_Pokaz_2019.pdf (дата обращения: 12.08.2020).

${ }^{2}$ Богдо-гэгэн - глава буддийской сангхи Монголии, один из высших лам традиции гелуг, глава традиции джонанг; третье, после Далай-ламы и Панчен-ламы, лицо в тибетском буддизме. Восьмой Богдо-гэгэгн, носитель титула Джебцун Дамба хутухта (1870-1924) - известен как Богдо-хан. В 1911 г. стал вождём национальной революции, установившей независимость Монголии от Китая; установил в стране теократическое правление (Буддизм, 1992: 47).
} 
очередь с его учениями. Духовный лидер на них дает объяснения, комментарии по буддийским классическим трактатам, а также посвящения. На подобные мероприятия едут паломники из числа народов, традиционно исповедующих буддизм, а также буддисты с Запада.

По воспоминаниям нашего респондента А., в 2005 г. на Учении Его Святейшества от Тувы было 20 человек, в 2006 г. - стало уже 60 чел., в 2007 г. - 42 чел. (ПМА, 2020). При этом 2007 г. знаменателен тем, что тогда Россия и Монголия проводили дни Российской культуры в индийской Дхарамсале Индии и это мероприятие возобновлял главный лама Калмыкии Тело Тулку Ринпоче. Тувинскую делегацию возглавил Камбы-лама Джамбел Лодой ${ }^{1}$, организация всей поездки велась Управлением Камбыламы Тувы (единственный раз) вместе с фондом «Сохраним Тибет». Возросшее число паломников из буддийских регионов России в Индию на Учения Далай-ламы привело к тому, что с 2009 г. по просьбе ламы Бурятии Ело Ринпоче, верховного ламы Калмыкии Тэло Тулку Ринпоче и при поддержке главы тувинских буддистов Лобсанга Чамзы (2014-2019 гг.) проводятся отдельные учения для россиян: в 2009-2014, 2016, 2019 гг. ${ }^{2}$

Общая численность российских паломников (а также из стран СНГ) в 2009 г., по данным Э.-Б. М. Гучиновой, составила 800 чел., в 2010 г. - 1200 чел., а в 2011 г. - 1600 чел. Организаторами выступали Буддийский центр «Ринпоче Багша» (Бурятия), Центральный хурул «Золотая обитель Будды Шакьямуни» (Калмыкия) и Фонд содействия сохранению культурных и философских традиций тибетского буддизма «Сохраним Тибет» (Москва). Эти учения были и остаются особо востребованными у российских буддистов в связи с невозможностью приезда Далай-ламы в Россию. При этом специальные учения зимой проходят в Индии (обычно в новогодние каникулы, см. фото 2) и весной-летом - в Риге (обычно в майские праздничные и выходные дни). Латвия выбирается организаторами в связи с тем, что она граничит с Россией, а латвийское правительство не боится испортить отношения с КНР, выдавая визу Далай-ламе (Гучинова, 2020b: 35). Правда, там Учения проводятся под другим названием «Учения для стран Балтии и России» ${ }^{3}$.

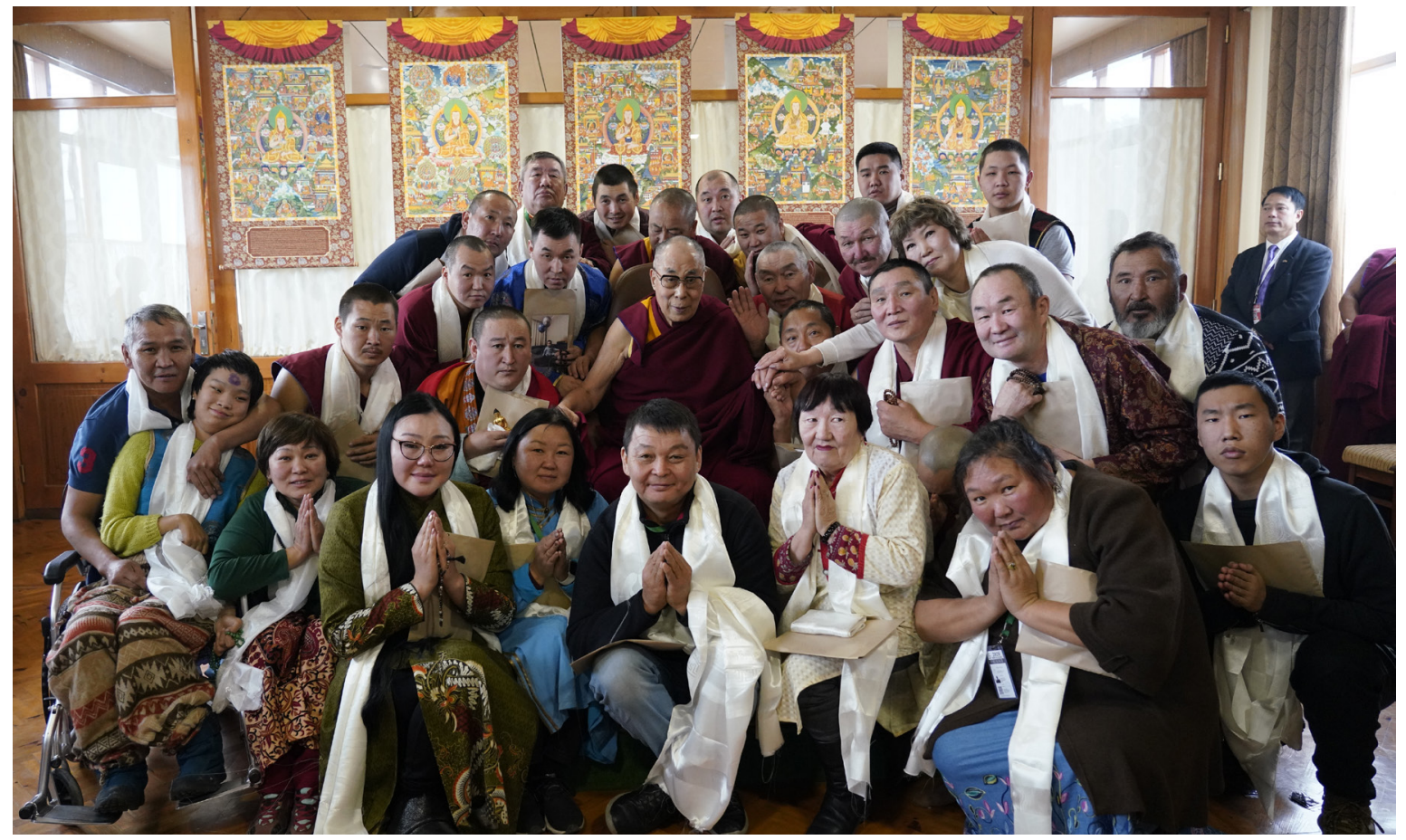

Фото 2. Тувинские паломники в резиденции Далай-ламы XIV, Бодгхая, штат Бихар, Индия, 2020 г.

Фото из архива Ю. Р. Хирбээ.

Photo 2. Tuvan pilgrims at the residence of the Dalai Lama XIV, Bodghaya, Bihar, India, 2020.

Photo from the personal archive of Y. R. Khirbe.

${ }^{1}$ Джамбел Лодой (Апыш-оол Шууракайович Сат) избирался Камбы-ламой Тувы дважды - в 2005-2010 гг., а также в 2019 г. Скончался 23 июня 2020 г.

${ }^{2}$ В 2020 г. Учения проводятся в онлайн-формате из-за пандемии короновируса.

${ }^{3}$ http://lv.dalailama.ru/?fbclid=IwAR1MxqRbY62oMJqD3KxtkLnObUvrCNCx8VJ2OK9s4jV2Ylb2tRjF5Vdj1Oc 


\section{НОВЫЕ ИССЛЕДОВАНИЯ ТУВЫ}

www.nit.tuva.asia
№4

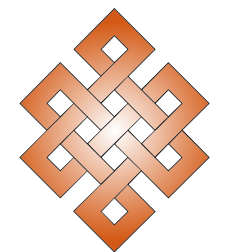

\section{THE NEW RESEARCH OF TUVA}

Novye issledovaniia Tuvy

По наблюдениям одного из наших респондентов, паломники в Индии преследуют много целей. Помимо учений Его Святейшества Далай-Ламы, они посещают медицинские центры, чтобы их осмотрели доктора восточной медицины: проверили пульс, диагностировали их состояние, дали им назначение. Многие паломники посещают астрологов, просят сделать астрологическую карту для себя и родственников, некоторые заказывают гадание. Если у кого-то большие проблемы, они обязательно посещают лам, заказывают большие молебны, где их читают 3000-5000 монахов (считается, что от этого сила молитв больше).

В Индии также совершаются паломничества по святым местам, связанным с жизнью Будды Шакьямуни. Считается важным посетить Бодхгаю, где Будда достиг просветления (фото 3); Варанаси, где он даровал свое первое учение о Четырех Благородных Истинах; Шравасти, где Будда провел 25 лет своей жизни, даруя учения; Кушинагар, где он ушел в паринирвану и многие другие святые места. Наши организаторы говорили о том, что выезжающие с ними в составе групп земляки могут уже в ходе поездки разделиться на несколько человек и по желанию посещать интересующие их места отдельно. Помимо этого, им рекомендуется заранее брать визы для выезда из Индии в Непал, где расположены буддийские святыни в долине Катманду: ступы Боднатх, Сваямбунатх, храмы. Из Дхарамсалы туда можно добраться маршрутом: автобусом до Нью-Дели, поездом и джипом до непальской границы. Отдельно малыми группами паломники ездят сами и в китайский Тибет, где традиционными местами паломничества считаются монастыри г. Лхаса и других местностей, пещеры, озеро Манасаровар, гора Кайлас и др.

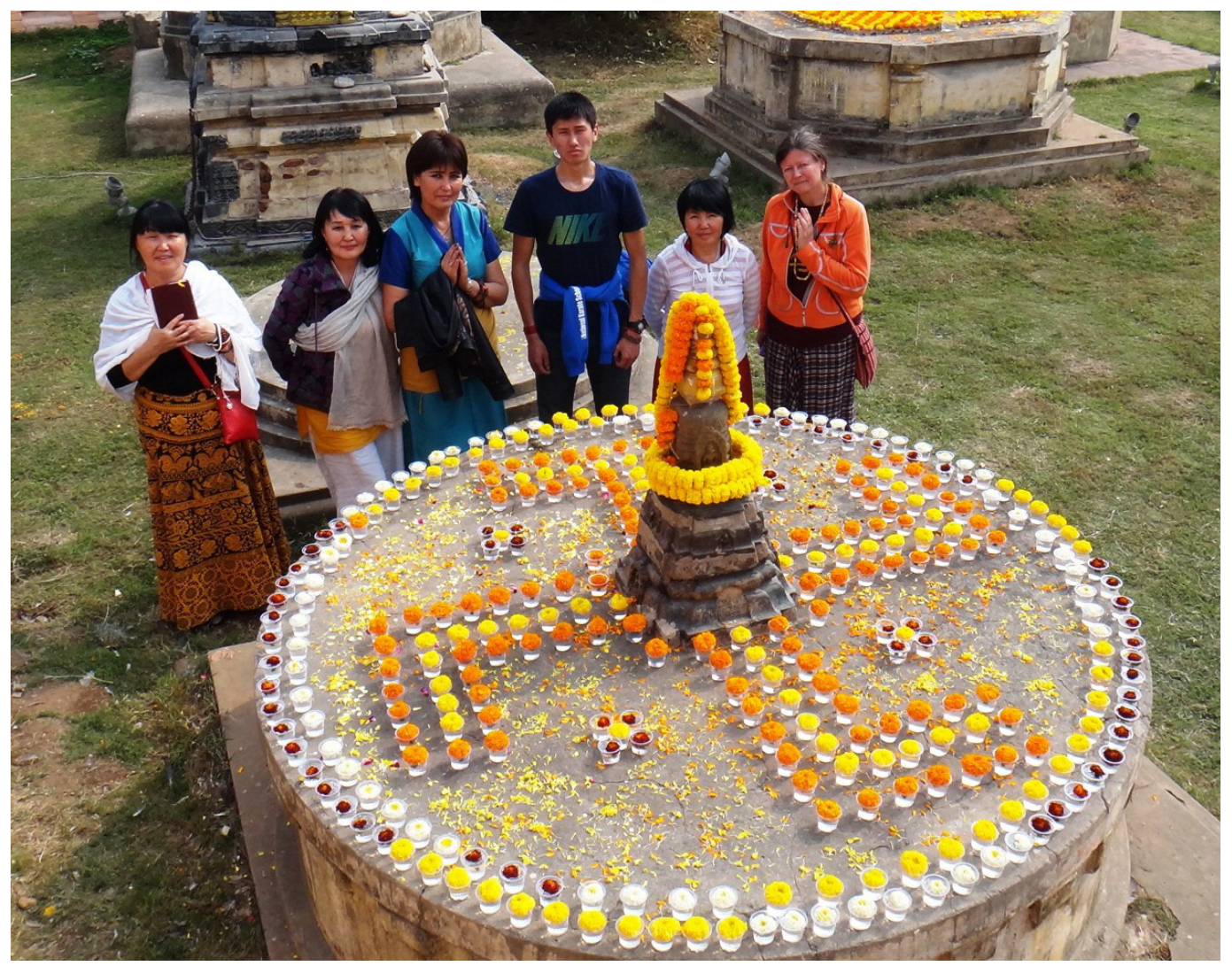

Фото 3. Группа буддистов из Тувы, Забайкалья и Москвы совершали подношение воды и цветов в саду храма Махабодхи в г. Бодхгае, штат Химчал-Прадеш, январь 2016 г. Фото из архива Р. Х. Джалиловой. Photo 3. A group of Buddhists from Tuva, Transbaikalia and Moscow in the town of Bodh Gaya, Himachal Pradesh, January 2016. Photo from the personal archive of R.Kh. Dzhalilova.

Традиционным буддийским направлением для тувинцев также осталась Монголия. Центром притяжения буддистов в этой стране остался крупнейший буддийский монастырь в Улан-Баторе Гандантэгчэнлин, который не закрывался в советские годы. Кроме всего прочего, данное направление и одно из самых экономичных, поскольку тувинцы могут добираться туда на автомашинах через российско-монгольскую границу. 


\section{НОВЫЕ ИССЛЕДОВАНИЯ ТУВЫ}

www.nit.tuva.asia

Если говорить о внутреннем паломничестве в пределах России, то для тувинских паломников привлекательна прежде всего Бурятия с Иволгинским дацаном (построен в 1945 г., единственный действовавший буддийский храм СССР), а также ретритами ${ }^{1}$ (фото 4) на берегу оз. Байкал (см. также: Содномпилова, Аманголова, 2020).

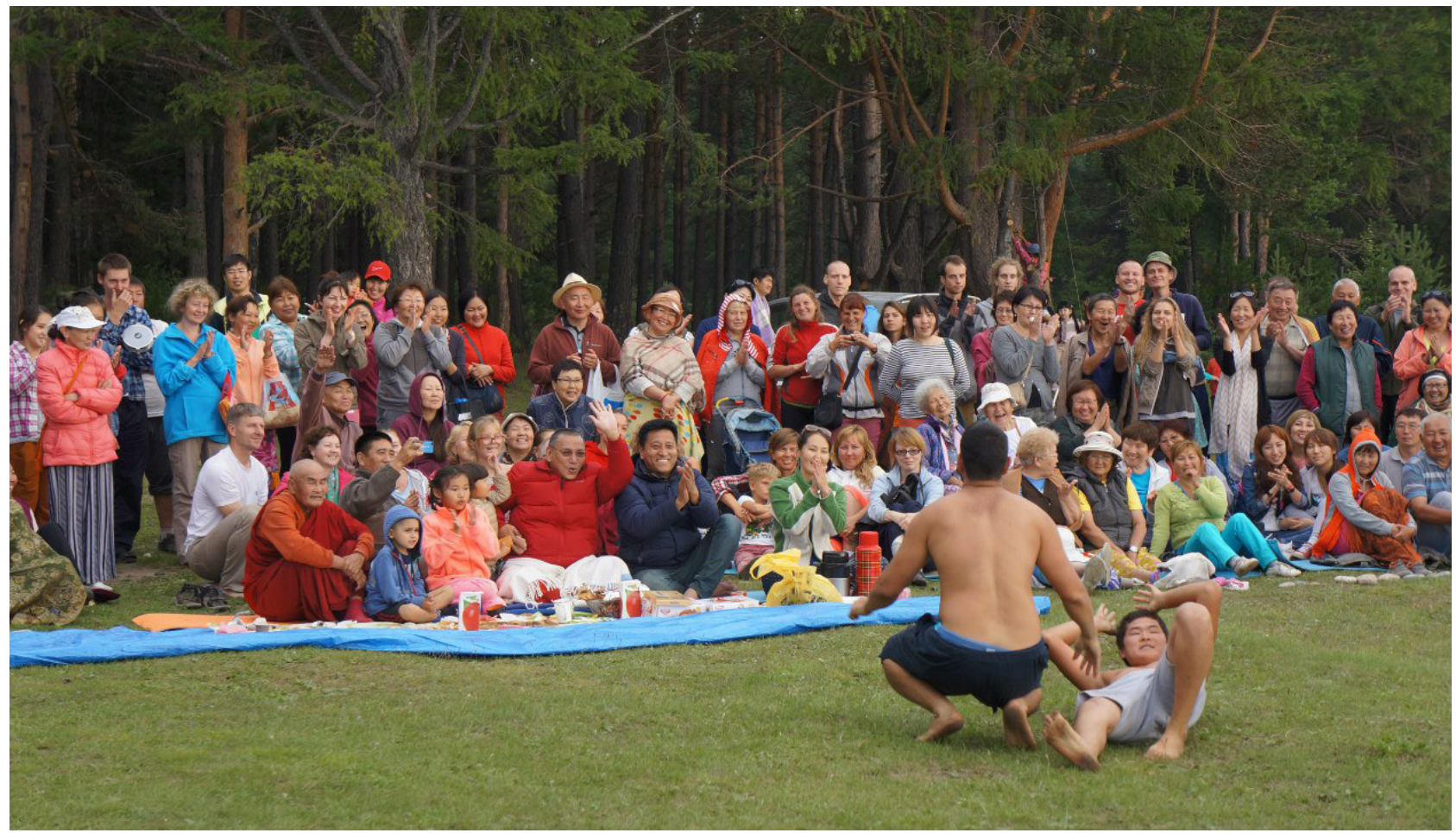

Фото 4. Борьба хуреш во время пикника. Ретрит в Байкальском медитационном центре под руководством Досточтимого геше Джампа Тинлея. Байкал, 2015 г. Фото Чойган Кужугет, из архива А. А. Конгу.

Photo 4. A khuresh wrestling match during a picnic. A retreat at the Baikal meditation center led by the Honorable geshe Dzhampa Tinlei. Baikal, 2015. Photo by Choigan Kuzhuget, from the archive of A. A. Kongu.

В г. Кызыле, например, работают буддийский центр «Манджушри»², молодежная организация «Субедейниң агымы», которые собирают своих членов на коллективные выезды для участия в ретритах по Ламриму ${ }^{3}$ на байкальских берегах. Значимые места для тувинских буддистов также: Дацан Гунзэчойнэй в Санкт-Петербурге (отмечающий в этом году 105-летие), а также хурул «Золотая обитель Будды» в Калмыкии, открывшийся в 2005 г. Внутреннее паломничество в пределах самой Тувы также развивается (к местным храмам, в том числе в недавно реконструированному Устуу хурээ в ДзунХемчикском кожууне, к месту Бурган Изи (След Бога) около с. Целинное Кызылского района, а также к субурганам и пр.).

Так, основных направлений зарубежного буддийского паломничества тувинцев три: южный (Индия, Непал, Тибет), юго-восточный (Монголия) и западный (Латвия и другие западные страны, где объявляется очередное учение Его Святейшества Далай-ламы XIV). Внутренних, российских главных направлений также три: восточное - Бурятия, западное - Калмыкия и северо-западное - Санкт-Петербург (см. общую схему маршрутов на рис. 1).

\footnotetext{
${ }^{1}$ Ретрит (от английского слова retreat - «затворничество», «уединение», «удаление от людей») - времяпрепровождение, которое посвящено медитативным практикам, уходу от плохих мыслей, мирской суеты.

${ }^{2}$ Созданный с благословения досточтимого Учителя Геше Джампа Тинлея, см.: Буддийские центры, созданные с благословения досточтимого Учителя Геше Джампа Тинлея [Электронный ресурс] // Централизованная религиозная буддийская организация Дже Цонкапа. URL: http:/geshe.ru/node/165 (дата обращения: 12.08.2020). ${ }^{3}$ Ламрим - руководства к ступеням Пути к полному Пробуждению в соответствии с учением Будды, распространённая среди тибетских буддистов. В буддийской традиции существует много разных версий Ламрима. Тувинские буддисты, как и другие российские, знакомы с переводной книгой: «Чжэ Цонкапа. Большое руководство к этапам Пути Пробуждения = lam rim chen mо» в переводе А. Кугявичюса, под редакцией А. А. Терентьева. (3-е изд. СПб.: Нартанг, 2010).
} 


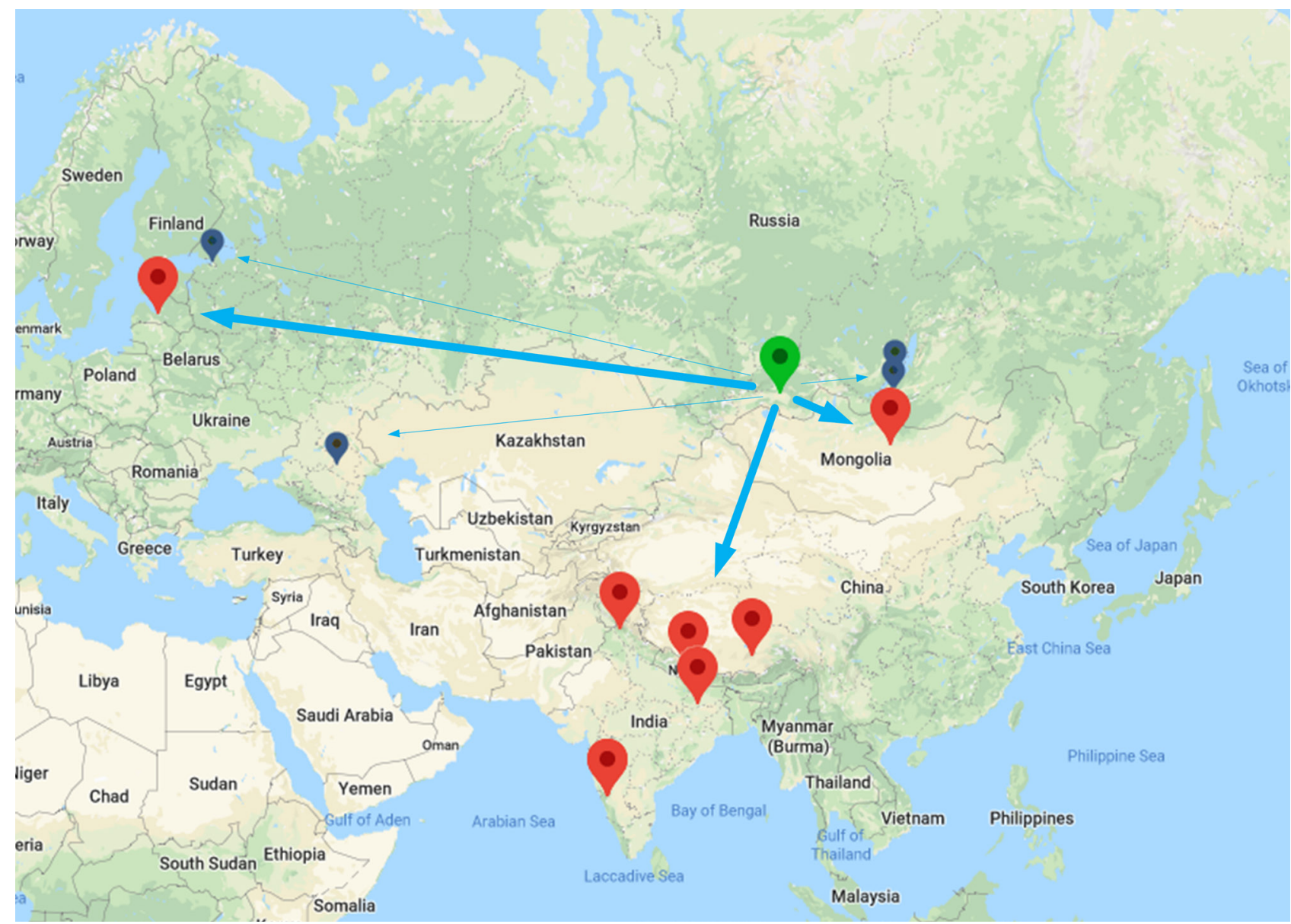

Рис. 1. Общая схема маршрутов паломничеств тувинских буддистов: в пределах России (тонкие голубые стрелки и синие метки) и за пределы страны (голубые широкие стрелки и красные метки) ${ }^{1}$. Нарисовано на основе карты Google.Maps. Fig. 1 The general pilgrimage map of Tuvan Buddhists: within Russia (blue marks, thin blue arrows) and outside Russia (red marks and bold blue arrows).

\section{От буддистов по традиции - к буддистам по вере}

Наши беседы с тувинскими паломниками выявили одну общую закономерность. Сначала респонденты считали себя буддистами по традиции (как результат простого самоотождествления личности с религиозным учением, см.: Мчедлова, 2017: 335), и лишь по мере взросления, духовных поисков они стали понимать, что этого недостаточно, и им надо стать буддистами по вере - людьми, которые разделяют постулаты религиозного учения:

«Я знал, что быть буддистом - это родиться в Туве, ходить в хурээ, ну и ставить чула»; «... просто поставил свечку в хурээ и ждал хорошего. И ламу звали домой» (респондент Б., муж., 31 год; ПМА, 2020);

«У меня бабушка с дедушкой, родители жили с большим уважением к ламам, так мы и росли, понимая себя буддистами», «Отец моей мамы, мой дедушка был ламой», «Ребенок не понимает, в какой среде он растет, и поскольку он в этом находится, он не понимает, что это может быть чем-то отдельным, он воспринимает это как единое целое. Я думаю, все вокруг, наверное, живут и воспитывают детей так...» (респондент 3., жен., 52 года; ПМА, 2020);

«...Я просто ходила в хурээ из-за того, что люди туда ходили. Я особо не задавалась вопросами религиозными. Просто чисто физическое тело приносила туда и все. Ничего не происходило на самом деле. А осознанно начала ходить в студенческие годы» (респондент А., жен., 29 лет; ПМА, 2020);

${ }^{1}$ В данной схеме даны только направления, без учета реальных маршрутов, связанных с местами сборов, пересадками, транзитными городами.

${ }^{2}$ Т. е. зажигать свечку. 
«В Туве почти все считают себя буддистами, ходят в хурээ на молитвы, например, студенты перед тем, как сдать экзамены - тоже», «Мы думаем, что мы - буддисты, а потом, когда ты уже начинаешь учить буддийскую философию, понимаешь, что ты - никто и вообще ничего не знаешь...» (респондент К., жен., 31 год; ПМА, 2020).

Эта особенность позволяет понять, что несмотря на высокие показатели числа буддистов, которые показывают традиционные социологические опросы в Туве (как и в других буддийских регионах $)^{1}$, буддистов, знающих основы учения, занимающихся буддийскими практиками (буддистов по вере), все же значительно меньше.

Что становится для людей поворотным пунктом, чтобы они поняли свою неосведомленность, осознали желание учиться, приобщиться к религиозной вере - к буддизму? В ходе наших бесед мы увидели пути, которые исследователи и проповедники и считают главными для обретения человеком веры: желание найти ответы на философские вопросы; попытки найти решение личных, семейных проблем; мистический опыт и встреча с духовным учителем.

И сами паломники, и организаторы паломничеств утверждают, что первая поездка может быть связана с любопытством, с желанием увидеть самого известного буддийского учителя современности и просто посмотреть другую страну как туристы. Разовые цели, например, ставят люди старшего поколения, как говорит Аян-оол башкы:

«Старшее поколение считает, что им надо хотя бы раз в жизни успеть посетить святые места. Еще они хотят посмотреть знаменитые индийские города, в том числе, например, Мумбаи» (ПМА, 2020);

«Иногда смотрю на людей и вижу, что они подготовленные, начитанные. ... Порой приходят со словами: “У меня есть лошади, скот... Ухаживая за ними, так и живу, не видя других мест... С вами бы побывать в Непале, на реке Ганг, потрогать хоть разок святое дерево Бодхи, прислонить голову к нему и вернуться. После этого в этой жизни ни о чем бы не жалела”. Так мне говорила одна женщина, я даже умилился» (ПМА, 2020).

Наши паломники в подобных случаях сначала ведут себя как туристы. Но тем не менее, они не простые туристы, а те, которые относятся к разряду религиозных туристов, ищущих знания.

Тут надо сказать, что есть ряд исследователей паломничества, которые считают некорректным применять к нему термины, заимствованные из туристической индустрии: «тур», «паломнический тур» и пр. (напр.: Житнев, 2012: 18). Русская Православная Церковь также выступает против коммерциализации паломничества и необходимость законодательного разделения понятий «паломничество» и «туризм» (там же) $)^{2}$. Однако, очевидно, что это конфессиональная позиция. И, как показывают исследования, она может складываться в связи с тем, что принимающая сторона (священнослужители, которые заботятся о святых местах, реликвиях) воспринимает туристов как некую угрозу. Религиозные хозяева считают, что благопристойность и безопасность в религиозных местах могут быть скомпрометированы присутствием туристов. Например, так описывают позицию индуистских общин С. А. Джозеф и A. Кавури (Joseph, Kavoori, 2001). Кроме того, опасения может вызывать и влияние массовых посещений на экологию священных мест (Shinde, 2007).

Тем не менее, современные формы паломничеств стали включать в себя поведение, которое традиционно было типичным для обычного туризма³ (Mustonen, 2006). Даже сам туризм был переосмыслен научным знанием. Так, Д. Макканел еще в 1970-е гг. туризм предложил рассматривать как ритуал, выполняемый в соответствии с различными видами дифференциации в обществе, и посещение дос-

\footnotetext{
${ }^{1}$ Например, в нашем последнем социологическом исследовании религиозности молодежи Тувы 2019 г., мы получили показатель 68,3\% считающих себя буддистами (Бадмаев и др., 2020: 38).

2 Данная позиция была поддержана российскими законодателями: паломническая деятельность относится только к действию Федерального закона «О свободе совести и о религиозных объединениях (с изменениями на 2 декабря 2019 года)» (статья 17-1), и подчеркнуто не относится к законодательству о туристской деятельности (статья 2). См.: О свободе совести и о религиозных объединениях (с изменениями на 2 декабря 2019 года) [Электронный ресурс] // Электронный фонд правовой и нормативно-технической документации. URL: http:// docs.cntd.ru/document/9040821; Об основах туристской деятельности в Российской Федерации (с изменениями на 8 июня 2020 года) [Электронный ресурс] // Электронный фонд правовой и нормативно-технической документации. URL: http://docs.cntd.ru/document/9032907 (дата обращения: 12.08.2020).

${ }^{3}$ Соотношение нынешних форм и практик паломничества и туризма позволяют в целом обсуждать тему соотношения, взаимодействия между религиозным и светским, традиционным и современным (Bremer, 2004).
} 
топримечательностей трактовать как своего рода коллективное стремление превозмочь разрыв современности, объединить фрагменты в общий опыт. Движущей силой туристов он считает дефицит подлинности в их повседневной жизни, и поэтому главная их потребность состоит в переживании этой подлинности (Макканел, 2016; Кормина, 2019: 40). Это и сближает его с паломниками.

В обсуждениях форм буддийского паломничества также присутствуют различения религиозного и светского видов. Во втором случае речь идет о паломничестве людей, проявляющих интерес к буддийским святыням мирян-небуддистов (Ерохина, 2019: 135-136).И, очевидно, этот опыт паломничества мирян - в форме религиозного туризма позволяет в дальнейшем им развить в себе интерес к буддизму настолько, что способствует именно внутреннему переходу от «буддиста по традиции» - К «буддисту по вере». Разумеется, такой путь проходят не все, но тем не менее, именно так интерпретируют туристов и их потенциал сами буддийские монахи, которые выступают принимающей стороной паломниковтуристов. Как показали в своем исследовании К. Вонг, А. Макинтош и К. Райан (Wong, McIntosh, Ryan, 2013), монахи одного из китайского буддийского монастыря полагают, что не следует воспринимать мирскую классификацию посетителей в строгом и абсолютном смысле, что личность каждого человека может меняться с течением времени. Если вначале туристы, даже просто отдыхающие (т. н. культурные туристы), приезжают, мало или ничего не зная о буддизме, и они могут жечь благовония только для удовольствия, тем не менее все они несут в себе «семя буддиста» (Buddhist's seed). Пройдет время, их «семя буддиста» вырастет, природа желаний расширится за пределы их собственного благополучия, чтобы в конечном счете охватывать всех живых существ. Тогда они перейдут из начальной стадии веры в буддизм к стадии обучения у Будды и поиску самопросветления (там же: 226). Так, «постепенный процесс посвящения и понимания буддизма в конечном счете приведет буддийскую природу индивидуума к прогрессу от спящего режима, относящегося к будущему буддисту, к более пробужденному режиму, относящемуся к буддийскому практикующему» (там же: 228). Таким образом, для буддистов нет жестких противопоставлений паломников от туристов. Большинство опрошенных исследователями респондентов-монахов воспринимают туризм положительно, потому что видят в нем канал, позволяющий большему количеству людей узнать о буддизме даже ценой влияния на их монашескую жизнь (там же: 229).

Известно, что сам Далай-лама XIV положительно относится к международному туризму, который он расценивает как средство «для улучшения личных контактов между людьми во всём мире» (Тензин Гятцо ... , 2000: 299). А цель паломничества он видит в душевном воодушевлении каждого человека:

«Визит в Бодх-Гаю стал для меня источником глубокого вдохновения. Любой верующий буддист всегда связывает Бодх-Гаю с тем, что в нашем религиозном и культурном наследии является наиболее возвышенным и почитаемым. С самого детства я думал и мечтал об этом визите и вот теперь я стоял на том священном месте, где святая душа, достигшая Махапаринирваны - высшей Нирваны, нашла путь к спасению для всех существ. Когда я стоял там, мое сердце переполнило чувство духовного воодушевления и оставило меня в задумчивости о том знании и воздействии божественной силы, которая есть в каждом из нас» (там же: 153).

Такой же момент прорастания «семян буддиста», духовного воодушевления продемонстрировали нам в рассказах о личных историях наши респонденты. Например:

«Приезжаешь с чисто интеллектуальным интересом.... А потом с молитвами это приходит само собой. Ты уже видишь, что это работает. Ты уже видишь эту защиту... уже понимаешь, что находишься под защитой трёх драгоценностей...», «Потом я начала пересматривать свои жизненные принципы. Оказывается, это придает силу духа, а сила духа приходит от знаний... Ты уже знаешь, как себя вести, начинаешь чувствовать тонкие буддийские практики...» (респондент Ч., жен., 40 лет; ПМА, 2020).

Так, наши паломники едут как туристы, однако, как туристы, имеющие религиозные цели: увидеть, поклониться, приобщиться, получить новые знания и особые впечатления. И тем самым подпитать

Трактовка самой религии как общественно-сконструированного явления позволило говорить о том, что как и все социально сконструированные миры, религия - это неустойчивое явление, зависимое от историко-культурных условий (Бергер, 2019: 41-42). Так, расшаталось представление о религии как нечто само собой разумеющемся (Узланер, 2020). В том числе стало возможным говорить о видах паломничества - религиозном и светском, разница между которыми заключается в контекстах их формирования и бытования, а также в объектах поклонения (Калужникова, 2007: 7-8). Светское паломничество понимается практически как синоним религиозного туризма, для которого приоритетными целями являются образование, отдых и развлечение, и только потом - религиозные и духовно-нравственные цели (Павличенко, Давыденко, 2018: 137). 


\section{НОВЫЕ ИССЛЕДОВАНИЯ ТУВЫ}

www.nit.tuva.asia

№4

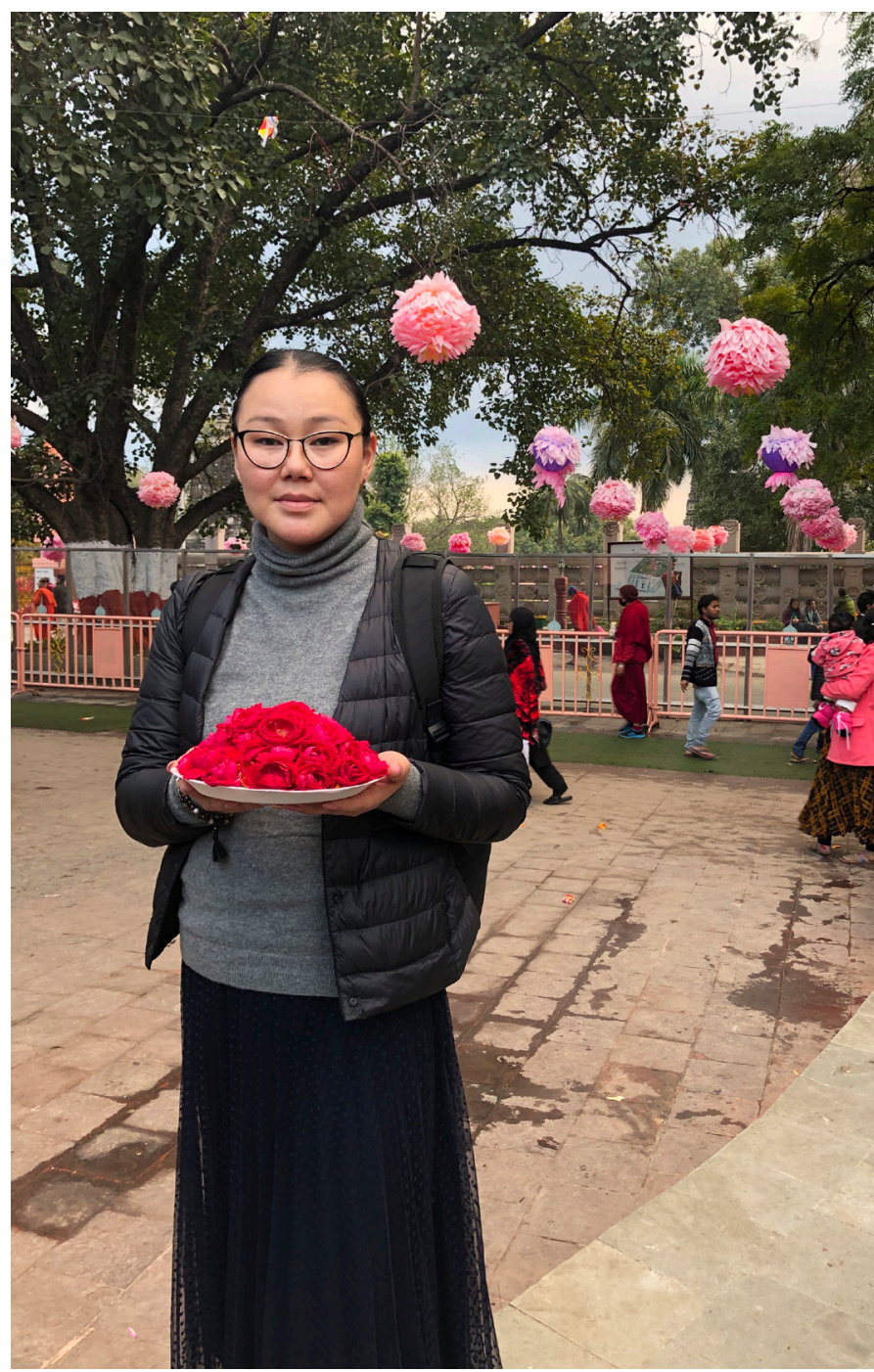

Фото 5. Паломница из Тувы Юлия Романовна Хирбээ, Бодгхая, штат Бихар, Индия, 2020 г. Фото из архива Ю. Р. Хирбээ.

Photo 5. Yulia Romanovna Khirbee in Bodh Gaya, Bihar, India, 2020. Photo from the personal archive of Yu.R. Khirbee.

2010: 330).

Поэтому самой главной, популярной целью паломничества, в том числе такого его варианта как светское паломничество или религиозный туризм, который поощряется организаторами паломничеств, остаются учения Далай-ламы (фото 6). Дело в том, что в самом буддизме участие в учениях Его Святейшества Далай-ламы воспринимается далеко не просто, как прослушивание лекций, устная передача некоей суммы знаний. Когда иерарх «зачитывает вслух классическое произведение по философии буддизма, считается, что слушатель не просто воспринимает его содержание на интеллектуальном уровне, но также получает от учителя некий энергетический импульс, способствующий глубокому проникновению в его суть. Этот импульс, который тибетцы называют “благословением линии преемственности”, распространяется не только на нынешнюю жизнь, но и на последующие перерождения» (Далай-лама, 2015: 13).

И откровения наших респондентов показывают нам, какими глубокими могут быть впечатления у них от одного созерцания духовного лидера:

«В 2005 году я впервые в Монголию поехала, чтобы увидеть Его Святейшество Далайламу. До этого я ни разу не видела его, поэтому мне очень хотелось побывать на его учениях, посмотреть на живого Будду, получить благословение»; «Я достигла своей цели. Это если судить 


\section{НОВЫЕ ИССЛЕДОВАНИЯ ТУВЫ}

\section{THE NEW RESEARCH OF TUVA}

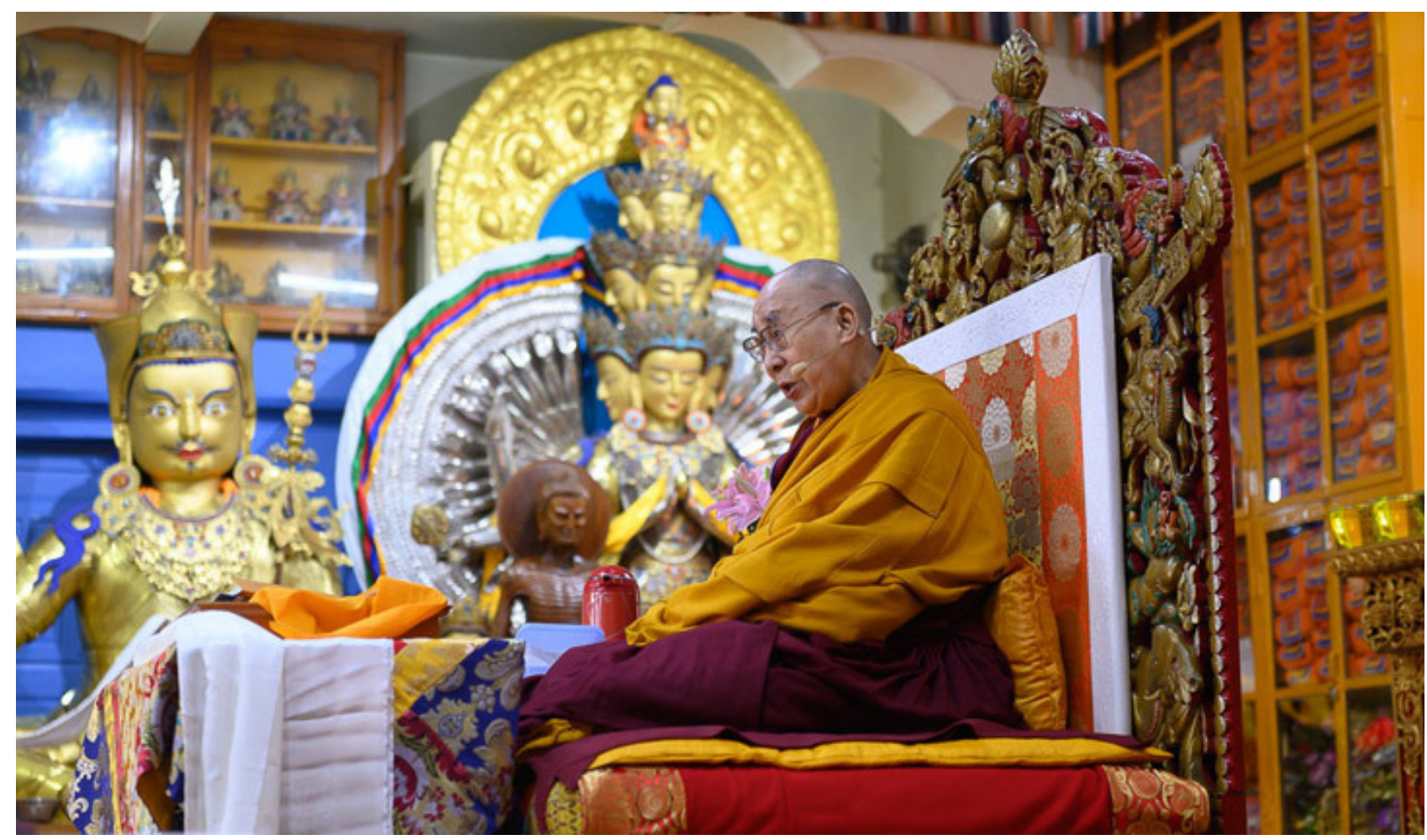

Фото 6. Его Святейшество Далай-лама дарует учения для буддистов России в тибетском храме Цуглакханге, Индия, 2019. Фото Тензин Чойджор. Фото с сайта Его Святейшества Далай-ламы XIV.

Photo 6. His Holiness the Dalai Lama presents his teachings to the Buddhists of Russia at the Tibetan temple of Tsuglakkhange. India, 2019, Photo by Tenzin Choidzhor. Photo courtesy of the website of His Holiness the Dalai Lama XIV.

с мирской точки зрения. Если в духовном аспекте, то получить благословение от такого великого наставника, учителя, это, наверно, для каждого важно, т. к. дарит душевное спокойствие, чувство удовлетворения» (респондент Р., жен., 42 года; ПМА, 2020);

«Поехала, вообще, чтобы увидеть Далай-Ламу... Чтобы совместить приятное с полезным, т. е. попутешествовать. Вообще это все было спонтанно, я не планировала. Подруга сказала: “Поехали?!”, мы начали бронировать места, купили билеты и т. д.», при встрече с Далай-ламой: "Мы все ждали около гостиницы. Вся толпа была у входа, там были железные ограды, все ждали и ждали... Его Святейшество вышел и начал всех приветствовать. Он начал всех благословлять, он улыбался, и он показался мне... Все остальные люди показались мне тусклыми, а он был такой сверкающий. Не знаю, почему-то он был поярче. Или может быть это просто мое, как бы, предубеждение, но я сама удивилась такому впечатлению...» (респондент Е., жен., 29 лет; ПМА, 2020);

«Я считаю, что все, что идет от Его Святейшества Далай-ламы - самое важное»; «Я точно не знаю, как ... это полезно. Каждый для себя определяет, почему это для него полезно. Для меня, в частности, такие учения - это как, в жизни план “Б”. В конечном счете все равно мне приходится покинуть этот мир, и буддийские учения дают такие наставления, которые помогают тебе немножко подготовиться. Рано или поздно эта жизнь закончится, и надо подготовиться к следующей жизни» (респондент Э., муж., 31 г.; ПМА, 2020).

Помимо этого, организаторы паломничеств поощряют общую любознательность своих подопечных, настроенных сначала как туристы:

«Вы хотите поехать только на 3 дня посмотреть на Далай-ламу? Лучше рассчитывайте на 7 дней, это будет очень хорошо, вы потом сами поймете. И они потом действительно говорят мне: “Иии! И правда хорошо, что вы нас направили, а то мы по незнанию действительно всего пару дней бы побывали”... Я говорю: “Вы заодно не только Далай-ламу увидите, но увидите других учителей, святые места увидите. Это большая удача. Можете на 7-10 дней остаться, разве у вас будут еще деньги снова вернуться?”. Они потом соглашаются. “Когда вы летите на Гоа ${ }^{1}$, Гоманг дацан заодно рядом посетите, это такой большой хурээ. В Дхарамсале таких больших нет, весь 
оплот учения находится только на юге”. Когда настаиваю, мне отвечают: “Нет-нет, все нормально, мы только посмотрим на Далай-ламу”. Тем не менее, они и Гоа посетят, и Гоманг дацан увидят, потом говорят: “Ии! И правда, вы нас правильно сподвигнули!”. Поэтому начинающих людей можно так наставлять...» (респондент 3., жен., 52 года; ПМА, 2020).

В конечном счете эти новые впечатления помогают сознанию расширяться, людям - меняться, считает Буян башкы:

«Конечно, все люди говорят о том, что они сначала съездили как туристы. Что им дало? Это другая страна, другая культура... В Индии очень много бедных, очень много больных. Очень многие люди страдают физически, морально. Они спят на улице... Вот это было для них шоком и они (туристы, паломники. - Ч. Л., У. Б., А. М.) начали ценить то, что у нас бесплатно. Много денег дают, есть различные государственные программы. Что у нас земли много, а там в Индии свободной земли почти нет. Поэтому это дает им ценность жизни и меняться в лучшую сторону» (ПМА, 2020).

Так, опекающие паломников ламы, буддисты - организаторы паломничеств, стараются вести своих подопечных по пути пробуждения в них «семян буддизма» к расширению сознания, что позволит им стать буддистами по вере.

\section{Заключение}

Наши интервью с паломниками, записанные в феврале-марте 2020 г., были выполнены на фоне стремительно меняющихся социальных условий: в мире разразилась пандемия COVID-19 и большинство стран приняли жесткие меры по нераспространению этого вируса, в том числе закрыв границы, посадив население на карантин или самоизоляцию. Сама расшифровка аудиозаписей и анализ уже проходили в условиях самоизоляции как авторов статьи, так и наших респондентов. Весь текущий год изменил планы огромного числа людей. Общественность и социальная наука заговорили о новой норме (new normal) в повседневной жизни. Элементами new normal стали: дистанцирование, минимизация контактов и перемещений людей. В этих условиях особую актуальность приобрело перемещение паломничества (как и других видов социальной активности) в киберпространство, уже знакомое, но настолько широко не использовавшееся (Павличенко, 2015). Его Святейшество Далайлама XIV стал давать учения из своего офиса в режиме онлайн-трансляций ${ }^{2}$. Но мы полагаем и надеемся на то, что это лишь временная ситуация, которая разрешится, и мир снова вернется к своим прежним социальным нормам, в том числе в плане паломнических движений.

В целом, в отличие от направления калмыцкого паломничества, которое организуется во-многом при помощи сангхи хурула «Золотая обитель Будды Шакьямуни» (Гучинова, 2020b), тувинское паломничество - как внешнее, так и внутреннее - развивается в большей степени как стихийный процесс. Движение не имеет централизованной организации, не поддерживается ни церковью, никакими организациями и тем более - правительством республики. Несмотря на организационные сложности, на затратность поездок, тувинские буддийские паломники под опекой специальных организаторовсопровождающих стремятся выезжать на буддийские учения в центры мирового буддизма, тем самым развивая зарубежное паломничество.

Однако, не все так гладко в этом движении. Как считает настоятель монастыря Дрепунг Гоманг, геше-лхарамба Лобсанг Гьялцен, на встрече с руководством Тувы в 2019 г. в г. Кызыле: «буддизм в Туве, если смотреть в целом, несколько увядает» ${ }^{3}$. Его волнует возможность реализации тувинских хуураков (на тот момент 17 юношей, обучающихся в данном монастыре) на родине, а также вопросы поддержки для мирян и всех тех, кто хочет постичь буддизм, но у которых нет двадцати лет на полное обучение. Гость выразил мнение, что «интерес к этому учению у тувинцев держится скорее из-за традиции, то есть как бы по инерции, но спасения в нем они не находят» ${ }^{4}$. Поэтому движение нуждается и в последующем обстоятельном изучении, и в организационной поддержке, о чем нам также говорили наши респонденты.

\footnotetext{
${ }^{1}$ Гоа - штат на юго-западе Индии, популярный у российских туристов.

${ }^{2}$ Архив 2020 год [Электронный ресурс] // Его Святейшество Далай-лама XIV. URL: https://ru.dalailama.com/ schedule/2020-schedule-archive (дата обращения: 12.08.2020).

${ }^{3}$ Константинов В. Изучение буддизма на священной индийской земле [Электронный ресурс] // Плюс информ. 2019, 28 августа. URL: https://plusinform.ru/publication/631 (дата обращения: 12.08.2020).

${ }^{4}$ Там же.
} 


\section{Благодарности}

Благодарим всех наших респондентов, любезно согласившихся на беседы, а также предоставивших фотографии с поездок. Спасибо большое за справки, консультации Э.-Б. М. Гучиновой (Калмыцкий научный центр РАН), Юлии Жиронкиной (Фонд «Сохраним Тибет»); за прорисовку карты - А. С. Папыну.

\section{СПИСОК ЛИТЕРАТУРЫ}

Абаев, Н. В., Хомушку, О. М., Бичелдей, У. П. (2013) Буддизм в Центральной Азии: история, основы учения и культура: учебное пособие. Кызыл : ТувГУ. 131 с.

Бадмаев, В. Н., Уланов, М. С., Ламажаа, Ч. К., Бичелдей, У. П., Антонов, В. И., Очирова, О. А. (2020) Россия и буддийский мир глазами молодежи Тувы, Бурятии и Калмыкии (по материалам социологического опроса) // Новые исследования Тувы. № 1. C. 35-49. DOI: https://doi.org/10.25178/nit.2020.1.3

Бергер, П. (2019) Священная завеса. Элементы социологической теории религии : пер. с англ. Р. Сафронова. М. : Новое литературное обозрение. 208 с.

Буддизм (1992): Словарь / Абаева Л. Л., Андросов В. П., Бакаева Э. П. и др.; под общ. ред. Н. Л. Жуковской, А. Н. Игнатовича, В. И. Корнева. М. : Республика. 288 с.

Ваторпин, А. С., Костина Н. Б., Подергина, Е. Е. (2017) Трансформация феномена паломничества в современном обществе // Дискуссия. № 7. С. 54-62.

Гидденс, Э. (1999) Социология. М. : Едиториал УРСС. 704 с.

Гучинова, Э.-Б. М. (2020а) Паломничество как путь к вере: опыт социального конструирования религиозности // Государство, религия, церковь в России и за рубежом. № 1 (38). С. 152-176. DOI: https://doi.org/10.22394/2073-72032020-38-1-152-176

Гучинова, Э.-Б. М. (2020b) С красной кистью и желтым галстуком: о специфике калмыцкого паломничества // Этнографическое обозрение. № 2. C. 32-46. DOI: https://doi.org/10.31857/S086954150009603-3

Далай-лама (2015) Вспышка молнии во мраке ночи. Краткий комментарий к «Бодхичарья-аватаре» Шантидевы: пер. с англ. и общ. ред. Ю. Жиронкиной, науч. ред. Б. Загуменнов. М. : Фонд «Сохраним Тибет». 176 с.

Дариева, Ц. А., Гучинова Э.-Б. М. (2020) Исследуя современное паломничество у монголоязычных народов России // Этнографическое обозрение. № 2. С. 5-12. DOI: https://doi.org/10.31857/S086954150009601-1

Ерохина, М. В. (2019) Буддийское паломничество в Индии: история и современность // Asiatica: Труды по философии и культурам Востока. Т. 13, № 2. С. 122-140.

Житенев, С. Ю. (2010) Религиозное паломничество : межкультурные коммуникации и цивилизационный контекст : автореф. дисс.... канд. ккультурологии. М. 26 с.

Житенев, С. Ю. (2012) Религиозное паломничество в христианстве, буддизме и мусульманстве: социокультурные, коммуникационные и цивилизационные аспекты. М. : Индрик. 186 с.

Жуковская, Н. Л. (1992) Ламаизм в Туве // Буддизм: Словарь / Абаева Л. Л., Андросов В. П., Бакаева Э. П. и др.; под общ. ред. Н. Л. Жуковской, А. Н. Игнатовича, В. И. Корнева. М. : Республика. 288 с. С. 167-168.

Жуковская, Н. Л. (2013) О буддизме и буддистах. Статьи разных лет. 1969-2011. М. : Ориенталия. 240 с.

История буддизма в СССР и Российской Федерации в 1985-1999 гг. (2010) / под общ. ред. Н. Г. Очировой. М. : Фонд современной истории. 392 с.

Калужникова, Е. А. (2007) Паломничество как ритуал : сущность и культурно-исторические типы : автореф. дис. ... кандидата культурологии. Екатеринбург. 23 с.

Кормина, Ж. В. (2019) Паломники. Этнографические очерки православного номадизма. М. : Издательский дом Высшей школы экономики. 351 с.

Ламажаа, Ч. К. (2019) Геокультурные образы буддийского мира тувинцев: исторический контекст и современность // Новые исследования Тувы. № 3. С. 27-40. DOI: https://doi.org/10.25178/nit.2019.3.3

Макканелл, Д. (2016) Турист. Новая теория праздного класса / пер. А. Боровикова, Е. Изотова. М. : Ад Маргинем Пресс. 279 с.

Монгуш, М. В. (1992) Ламаизм в Туве : историко-этнографическое исследование. Кызыл : Тувинское книжное издательство. $144 \mathrm{c.}$

Монгуш, М. В. (2001) История буддизма в Туве (вторая половина VI - конец XX в.). Новосибирск: Наука. 200 с. 
Монгуш, М. В. (2010) Индийская мозаика (часть первая) [Электронный ресурс] // Новые исследования Тувы. № 1. C. 311-331. URL: https://nit.tuva.asia/nit/article/view/585 (дата обращения: 03.08.2020).

Мунхбат, Д. (2018) Паломничество монголов: традиции и современность // Народы и религии Евразии. Т. 2 , № 15. С. 79-84. DOI: https://doi.org/10.14258/nreur(2018)2-07

Мчедлова, М. М. (2017) Религиозная и конфессиональная идентичность // Идентичность: Личность. Общество. Политика. Энциклопедическое издание / отв. ред. И. С. Семененко. М. : Весь Мир. 992 с. С. 334-339.

Павличенко, 3. Ю. (2015) Паломничество в киберпространстве // Вестник Кыргызско-Российского славянского университета. Т. 15, № 12. С. 106-109.

Павличенко, 3. Ю., Давыденко, М. В. (2018) Паломничество и религиозный туризм в Центральной Азии как форма межцивилизационных контактов // Известия АлтГУ. Исторические науки и археология. № 2. С. 136-139. DOI: https://doi.org/10.14258/izvasu(2018)2-23

Паломничество и религиозный туризм: многообразие интерпретация (2011) : сборник статей / редкол.: И.Е. Викулов (отв. ред.) и др. Владимир : Изд-во Владимирского гос. ун-та им. А. Г. и Н. Г. Столетовых. 209 с.

Содномпилова, М. М., Аманголова, Д. Д. (2020) Традиционные и новые места религиозного паломничества в Бурятии // Этнографическое обозрение. № 2. С. 47-60. DOI: https://doi.org/10.31857/S086954150009604-4

Тензин Гьятцо (Далай-лама XIV) (2000) Моя страна и мой народ. Воспоминания Его Святейшества Далай-ламы XIV / пер. А. Терентьева. СПб.: Нартанг ; Corvus. 320 с.

Узланер, Д. (2020) Постсекулярный поворот. Как мыслить о религии в XXI веке. М. : Институт экономической политики имени Е. Т. Гайдара. 187 с.

Уланов, М. С., Бадмаев В. Н., Андреева А. А. (2020) Феномен буддийского паломничества в истории и культуре калмыков // Былые годы. Т. 56, выпуск 2. С. 398-406. DOI: https://doi.org/10.13187/bg.2020.2.398

Феномен паломничества в религиях: священная цель, священный путь, священные реликвии (2006) : материалы XIII Санкт-Петербургских религиоведческих чтений / науч. ред. и сост. Т. Н. Дмитриева, И. Х. Черняк. СПб. : Гос. музей истории религии. 147 с.

Хомушку, О. М. (1998) Религия в истории культуры тувинцев. М. : Наука. 177 с.

Хомушку, О. М. (2005) Религия в культуре народов Саяно-Алтая. М. : РАГС. 225 с.

Хомушку, О. М., Кухта, М. С. (2016) Этноконфессиональный фактор в духовном возрождении Тувы: социальнофилософский анализ // Oriental Studies. № 27(5). С. 119-126.

Цыремпилов, Н. В. (2020) Москва как буддийский рай: бурятская депутация на коронации Николая II // Этнографическое обозрение. № 2. C. 13-31. DOI: https://doi.org/10.31857/S086954150009602-2

Эрендженова, Ю. Ю. (2020) Священные объекты в религиозной культуре российских буддистов: интенции и праксис // Вестник Калмыцкого университета. № 2 (46). С. 124-130.

Bremer, T. S. (2004) Blessed with tourists: The borderlands of religion and tourism in San Antonio. Chapel Hill and London: The University of North Carolina Press. 207 p.

Coleman, S. (2002) Do You Believe in Pilgrimage? Communitas, Contestation and Beyond // Anthropological Theory. Vol. 2(3). P. 355-368.

Collins-Kreiner, N. (2010) Researching pilgrimage: Continuity and Transformations // Annals of Tourism Research. Volume 37, Issue 2. P. 440-456. DOI: https://doi.org/10.1016/j.annals.2009.10.016

Joseph, C. A., Kavoori, A. P. (2001) Mediated resistance. Tourism and the host community// Annals of Tourism Research. № 28(4). P. 998-1009.

Kim, B., Kim, S., King B. (2020) Religious tourism studies: evolution, progress, and future prospects // Tourism Recreation Research. Vol. 45. P. 185-203. DOI: https://doi.org/10.1080/02508281.2019.1664084

McIntosh, I. S. (2020) Pilgrimage: Walking to Peace, Walking for Change. Xlibris Corporation. 250 p.

Mustonen, P. (2006) Volunteer Tourism: Postmodern Pilgrimage? // Journal of Tourism and Cultural Change. Vol. 3, issue 3. P. 160-177. DOI: https://doi.org/10.1080/14766820608668493

Shrines and pilgrimage in the modern world: New itineraries into the sacred (2008) / Ed. by P. J. Margry. Amsterdam University Press. 364 p.

Shinde, K. (2007) Pilgrimage and the Environment: Challenges in a Pilgrimage Centre // Current Issues in Tourism. Vol. 10, issue 4. P. 343-365. DOI: https://doi.org/10.2167/cit259.0 
Raj, R., Griffin, K. (ed.) (2015) Religious Tourism and Pilgrimage Management. An International Perspective. $2^{\text {nd }}$ ed. DOI: https://doi.org/10.1079/9781780645230.0000

Reframing pilgrimage : cultures in motion (2004) / ed. by S. Coleman and J. Eade. London ; New York : Routledge. 197 p. Sellner, E. C. (2004) Pilgrimage: Exploring A Great Spiritual Practice. Ave Maria Press. 220 p.

Turner, V., Turner, E. (1978) Image and Pilgrimage in Christian Culture. Columbia University Press. 344 p.

Wong, C. U. I., Mcintosh, A., Ryan, C. (2013) Buddhism and tourism perceptions of the monastic community at PuTuo-Shan, China // Annals of Tourism Research. Vol. 40. P. 213-234. DOI: http://dx.doi.org/10.1016/j.annals.2012.09.004

Дата поступления: 24.08.2020 2.

\section{REFERENCES}

Abaev, N. V., Khomushku, O. M. and Bicheldey, U. P. (2013) Buddizm v Tsentral'noi Azii: istoriia, osnovy ucheniia i kul'tura [Buddhism in Central Asia: history, basic teachings, and culture]: a textbook. Kyzyl, TuvGU. 131 p. (In Russ.).

Badmaev, V. N., Ulanov, M. S., Lamazhaa, Ch. K., Bicheldey, U. P., Antonov, V. I. And Ochirova, O. A. (2020) Rossiia i buddiiskii mir glazami molodezhi Tuvy, Buriatii i Kalmykii (po materialam sotsiologicheskogo oprosa) [Russia and the Buddhist world through the eyes of the youth in Tuva, Buryatia and Kalmykia: a sociological survey and its outcomes]. New Research of Tuva, no. 1, pp. 35-49. (In Russ.). DOI: https://doi.org/10.25178/nit.2020.1.3

Berger, P. (2019) Sviashchennaia zavesa. Elementy sotsiologicheskoi teorii religii [The Sacred Canopy: Elements of a Sociological Theory of Religion]: transl. from Engl. by R. Safronova. Moscow, Novoe literaturnoe obozrenie. 208 p. (In Russ.).

Buddizm [Buddhism] (1992): A dictionary / Abaeva L. L., Androsov V. P., Bakaeva E. P. et al., ed. by N. L. Zhukovskaya, A. N. Ignatovich and V. I. Kornev. Moscow, Respublika. 288 p. (In Russ.).

Vatorpin, A. S., Kostina N. B. and Podergina, E. E. (2017) Transformatsiia fenomena palomnichestva v sovremennom obshchestve [Pilgrimage phenomenon's transformation in the modern society]. Discussion, no. 7, pp. 54-62. (In Russ.).

Giddens, A. (1999) Sotsiologiia [Sociology]. Transl. from Engl. Moscow, Editorial URSS. 704 p. (In Russ.).

Guchinova, E.-B.M. (2020a) Palomnichestvo kak put' k vere: opyt sotsial'nogo konstruirovaniia religioznosti [Pilgrimage as a Path to Faith: an Essay on a Social Construction of Religiosity]. Gosudarstvo, religiia, tserkov' v Rossii i za rubezhom, no. 1 (38), pp. 152-176. (In Russ.). DOI: https://doi.org/10.22394/2073-7203-2020-38-1-152-176

Guchinova, E.-B. M. (2020b) S krasnoi kist'iu i zheltym galstukom: o spetsifike kalmytskogo palomnichestva [With a Red Brush and Yellow Tie: On Specificities of the Kalmyk Pilgrimage]. Etnograficheskoe obozrenie, no. 2, pp. 32-46. (In Russ.). DOI: https://doi.org/10.31857/S086954150009603-3

Dalai-lama (2015) Vspyshka molnii vo mrake nochi. Kratkii kommentarii $k$ «Bodkhichar'ia-avatare» Shantidevy [A flash of lightning in the dark of the night. A brief commentary on Shantideva's Bodhicharya avatar] : Transl. from Engl. and ed. by Yu. Zhironkina and B. Zagumennov. Moscow, Fond «Sokhranim Tibet». 176 p. (In Russ.).

Darieva, Ts. A., Guchinova E.-B. M. (2020) Issleduia sovremennoe palomnichestvo u mongoloiazychnykh narodov Rossii [Exploring Contemporary Pilgrimage among the MongolianSpeaking Peoples of Russia]. Etnograficheskoe obozrenie, no. 2, pp. 5-12. (In Russ.). DOI: https://doi.org/10.31857/S086954150009601-1

Erokhina, M. V. (2019) Buddiiskoe palomnichestvo v Indii: istoriia i sovremennost' [Buddhist pilgrimage in India: history and modernity]. Asiatica: Trudy po filosofii i kul'turam Vostoka, vol. 13, no. 2, pp. 122-140. (In Russ.).

Zhitenev, S. Yu. (2010) Religioznoe palomnichestvo : mezhkul'turnye kommunikatsii i tsivilizatsionnyi kontekst [Religious pilgrimage : cross-cultural communications and civilizational context] : Thesis of Diss.... Candidate of Cultural Studies. Moscow. 26 p. (In Russ.).

Zhitenev, S. Yu. (2012) Religioznoe palomnichestvo v khristianstve, buddizme i musul'manstve: sotsiokul'turnye, kommunikatsionnye i tsivilizatsionnye aspekty [Religious pilgrimage in Christianity, Buddhism, and Islam: sociocultural, communication, and civilizational aspects]. Moscow, Indrik. 186 p. (In Russ.).

Zhukovskaia, N. L. (1992) Lamaizm v Tuve [Lamaism in Tuva]. In: Buddizm [Buddhism] : A dictionary / Abaeva L. L., Androsov V. P., Bakaeva E. P. et al., ed. by N. L. Zhukovskaya, A. N. Ignatovich and V. I. Kornev. Moscow, Respublika. 288 p. Pp. 167-168. (In Russ.).

Zhukovskaia, N. L. (2013) O buddizme i buddistakh. Stat'i raznykh let. 1969-2011 [Of Buddhism and Buddhists. Articles of different years 1969-2011]. Moscow, Orientaliia. 240 p. (In Russ.).

Istoriia buddizma $v$ SSSR i Rossiiskoi Federatsii v 1985-1999 gg. [The history of Buddhism in the USSR and the Russian Federation in 1985-1990] (2010) / ed. by. N. G. Ochirova. Moscow, Fond sovremennoi istorii. 392 p. (In Russ.).

Kaluzhnikova, E. A. (2007) Palomnichestvo kak ritual : sushchnost' i kul'turno-istoricheskie tipy [Pilgrimage as a ritual: its essence and cultural and historical types]: Thesis of Diss.... Candidate of Cultural Studies. Ekaterinburg. 23 p. (In Russ.). 
Kormina, J. V. (2019) Palomniki. Etnograficheskie ocherki pravoslavnogo nomadizma [Pilgrims: Ethnographic Sketches of the Orthodox Nomadism]. Moscow, HSE Publishing House. 351 p. (In Russ.). DOI: doi.org/10.17323/978-5-7598-1939-4

Lamazhaa, Ch. K. (2019) Geokul'turnye obrazy buddiiskogo mira tuvintsev: istoricheskii kontekst i sovremennost' [Geocultural images of the Tuvan Buddhist world: historical context and modernity.]. New Research of Tuva, no. 3, pp. 27-40. DOI: https://doi.org/10.25178/nit.2019.3.3

MacCannell, D. (2016) Turist. Novaia teoriia prazdnogo klassa [The tourist: a new theory of the leisure class] / transl. by A. Borovikov and E. Izotov. Moscow, Ad Marginem Press. 279 p. (In Russ.).

Mongush, M. V. (1992) Lamaizm v Tuve : istoriko-etnograficheskoe issledovanie [Lamaism in Tuva: a historical and ethnographic study]. Kyzyl, Tuvan book publisher. 144 p. (In Russ.).

Mongush, M. V. (2001) Istoriya buddizma v Tuve (vtoraya polovina VI - konets XX v.) [The History of Buddhism in Tuva (latter half of the 6th - late 20th cc.)]. Novosibirsk, Nauka. 200 p. (In Russ.).

Mongush, M. V. (2010) Indiiskaia mozaika (chast' pervaia) [The Indian mosaic (Part one)]. New Research of Tuva, no. 1, pp. 311-331 [online] Available at: https://nit.tuva.asia/nit/article/view/585 (access date: 03.08.2020). (In Russ.).

Munkhbat, D. (2018) Palomnichestvo mongolov: traditsii i sovremennost' [Mongols on pilgrimage: traditions and the present]. Nations and religions of the Eurasia, vol. 2, no. 15, pp. 79-84. (In Russ.). DOI: https://doi.org/10.14258/ nreur(2018)2-07

Mchedlova, M. M. (2017) Religioznaia i konfessional'naia identichnost' [Religious and confessional identity]. In: Identichnost': Lichnost'. Obshchestvo. Politika. Entsiklopedicheskoe izdanie [Identity: Personality. Society. Politics. An encyclopedia] / ed. by I. S. Semenenko. Moscow, Ves' Mir. 992 p. Pp. 334-339. (In Russ.).

Pavlichenko, Z. Yu. (2015) Palomnichestvo v kiberprostranstve [Pilgrimage in the cyberspace]. Vestnik KRSU, vol. 15, no. 12, pp. 106-109. (In Russ.).

Pavlichenko, Z. Yu. and Davydenko, M. V. (2018) Palomnichestvo i religioznyi turizm v Tsentral'noi Azii kak forma mezhtsivilizatsionnykh kontaktov [Pilgrimage and Religious Tourism in Central Asia as a Form of Intercivilization Contacts]. Izvestiya of Altai State University, no. 2, pp. 136-139. (In Russ.). DOI: https://doi.org/10.14258/izvasu(2018)2-23

Palomnichestvo i religioznyi turizm: mnogoobrazie interpretatsiia [Pilgrimage and religious tourism: a multitude of interpretations] (2011) : collected papers / ed. by I. E. Vikulov et al. Vladimir, Izd-vo Vladimirskogo gos. un-ta im. A. G. i N. G. Stoletovykh. 209 p. (In Russ.).

Sodnompilova, M. M., Amangolova, D. D. (2020) Traditsionnye i novye mesta religioznogo palomnichestva v Buriatii [Traditional and New Places of Religious Pilgrimage in Buryatia]. Etnograficheskoe obozrenie, no. 2, pp. 47-60. (In Russ.). DOI: https://doi.org/10.31857/S086954150009604-4

Tenzin Gyatso (Dalai Lama XIV) (2000) Moia strana i moi narod. Vospominaniia Ego Sviateishestva Dalai-lamy XIV [My Land and My People: The Original Autobiography of His Holiness the Dalai Lama of Tibet] / transl. by A. Terent'ev. St. Petersburg, Nartang, Corvus. 320 p. (In Russ.).

Uzlaner, D. (2020) Postsekuliarnyi povorot. Kak myslit' o religii v XXI veke [Post-secular turn. How to think about religion in the 21st century]. Moscow, Institut ekonomicheskoi politiki imeni E. T. Gaidara. 187 p.

Ulanov, M. S., Badmaev V. N., Andreeva A. A. (2020) Fenomen buddiiskogo palomnichestva v istorii i kul'ture kalmykov [The Phenomenon of Buddhist Pilgrimage in the History and Culture of Kalmyks]. Bylye Gody, vol. 56, issue 2, pp. 398-406. (In Russ.). DOI: https://doi.org/10.13187/bg.2020.2.398

Fenomen palomnichestva $v$ religiiakh: sviashchennaia tsel', sviashchennyi put', sviashchennye relikvii [The phenomenon of pilgrimage in different religions: sacred goals, sacred paths, sacred relics] (2006): Materials of the 13th St. Petersburg religious studies readings / ed. and comp. by T. N. Dmitriev and I. Kh. Cherniak. St. Petersburg, Gos. muzei istorii religii. 147 p. (In Russ.).

Khomushku, O. M. (1998) Religiia v istorii kul'tury tuvintsev [Religion in the history of Tuvan culture]. Moscow, Institut etnologii i antropologii RAN. 177 p. (In Russ.).

Khomushku, O. M. (2005) Religiia v kul'ture narodov Saiano-Altaia [Religion in the culture of the Sayano-Altai peoples]. Moscow, RAGS. 225 p. (In Russ.).

Khomushku, O. M. and Kukhta, M. S. (2016) Etnokonfessional'nyi faktor v dukhovnom vozrozhdenii Tuvy: sotsial'nofilosofskii analiz [The Ethno-Confessional Factor in the Spiritual Revival of Tuva: a Social and Philosophical Analysis]. Oriental Studies, no. 27(5), pp. 119-126. (In Russ.).

Tsyrempilov, N. V. (2020) Moskva kak buddiiskii rai: buriatskaia deputatsiia na koronatsii Nikolaia II [Moscow as a Buddhist Paradise: A Buryat Delegation at the Coronation of Nicholas II]. Etnograficheskoe obozrenie, no. 2, pp. 13-31. (In Russ.). DOI: https://doi.org/10.31857/S086954150009602-2 
Erendzhenova, Yu. Yu. (2020) Sviashchennye ob"ekty v religioznoi kul'ture rossiiskikh buddistov: intentsii i praksis [The holy objects in religious culture of Russian Buddhists: intentions and praxis]. Vestnik Kalmytskogo universiteta, no. 2 (46), pp. 124-130. (In Russ.).

Bremer, T. S. (2004) Blessed with tourists: The borderlands of religion and tourism in San Antonio. Chapel Hill and London: The University of North Carolina Press. 207 p.

Coleman, S. (2002) Do You Believe in Pilgrimage? Communitas, Contestation and Beyond. Anthropological Theory, vol. 2(3), pp. 355-368.

Collins-Kreiner, N. (2010) Researching pilgrimage: Continuity and Transformations. Annals of Tourism Research, vol. 37, issue 2, pp. 440-456. DOI: https://doi.org/10.1016/j.annals.2009.10.016

Joseph, C. A. and Kavoori, A. P. (2001) Mediated resistance. Tourism and the host community. Annals of Tourism Research, no. 28(4), pp. 998-1009.

Kim, B., Kim, S., King B. (2020) Religious tourism studies: evolution, progress, and future prospects. Tourism Recreation Research, vol. 45, pp. 185-203. DOI: https://doi.org/10.1080/02508281.2019.1664084

McIntosh, I. S. (2020) Pilgrimage: Walking to Peace, Walking for Change. Xlibris Corporation. 250 p.

Mustonen, P. (2006) Volunteer Tourism: Postmodern Pilgrimage? Journal of Tourism and Cultural Change, vol. 3, issue 3, pp. 160-177. DOI: https://doi.org/10.1080/14766820608668493

Shrines and pilgrimage in the modern world: New itineraries into the sacred (2008) / Ed. by P. J. Margry. Amsterdam University Press. 364 p.

Shinde, K. (2007) Pilgrimage and the Environment: Challenges in a Pilgrimage Centre. Current Issues in Tourism, vol. 10, issue 4, pp. 343-365. DOI: https://doi.org/10.2167/cit259.0

Raj, R., Griffin, K. (ed.) (2015) Religious Tourism and Pilgrimage Management. An International Perspective. 2nd ed. DOI: https://doi.org/10.1079/9781780645230.0000

Reframing pilgrimage : cultures in motion (2004) / ed. by S. Coleman and J. Eade. London; New York, Routledge. 197 p.

Sellner, E. C. (2004) Pilgrimage: Exploring A Great Spiritual Practice. Ave Maria Press. 220 p.

Turner, V. and Turner, E. (1978) Image and Pilgrimage in Christian Culture. Columbia University Press. 344 p.

Wong, C. U. I., Mcintosh, A. and Ryan, C. (2013) Buddhism and tourism perceptions of the monastic community at PuTuo-Shan, China. Annals of Tourism Research, vol. 40, pp. 213-234. DOI: http://dx.doi.org/10.1016/j.annals.2012.09.004

Submission date: 24.08.2020. 